ORRL/FEDC--83/11

DE\&5 $\quad 004387$

Fusion Energy Division

\title{
ANALYSIS OF TANDEM MIRROR REACTOR PERFORMANCE
}

Motice This cocument contuins information of a preliminery nature. It is ubject to revision or correction end therefore does not reprecents final repore.

K. F. Wu

Engineering Division

R. B. Campbell

TRW Defense and Space Systems, Inc.

Y-K. M. Peng

Fusion Energy Division

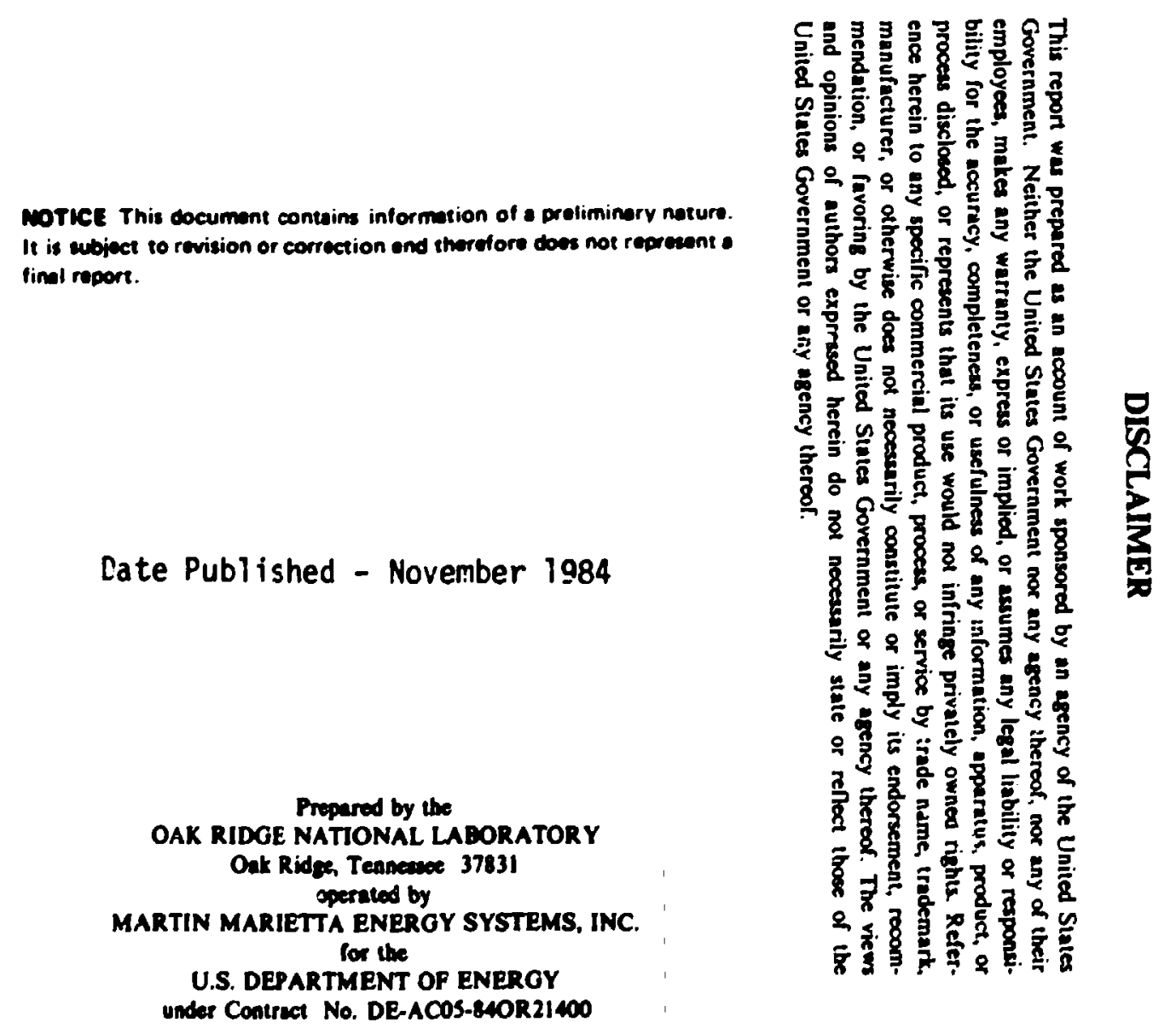

under Contruct No. DE-ACOS-84OR21400 


\section{CONTENIS}

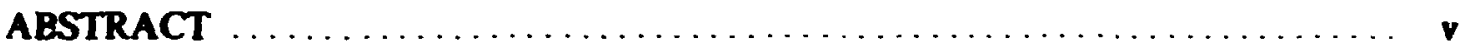

1. INTRODUCTION $\ldots \ldots \ldots \ldots \ldots \ldots \ldots \ldots \ldots \ldots \ldots \ldots \ldots \ldots \ldots$ !

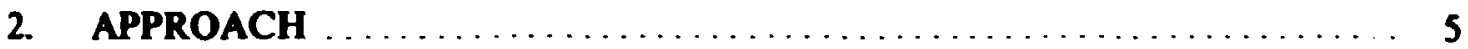

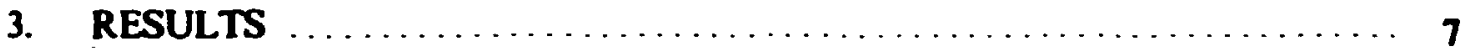

3.1 STUDIES OF THE PJ.UG REGION $\ldots \ldots \ldots \ldots \ldots \ldots \ldots \ldots \ldots \ldots$ ?

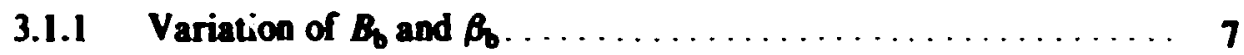

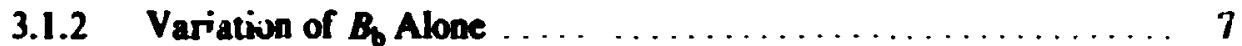

3.1.3 Variation of $\mathbf{g}$ and $\boldsymbol{G} \ldots \ldots \ldots \ldots \ldots \ldots \ldots \ldots \ldots \ldots$

3.1.4 Variation of $\boldsymbol{F}_{\boldsymbol{c}} \ldots \ldots \ldots \ldots \ldots \ldots \ldots \ldots \ldots \ldots \ldots \ldots \ldots \ldots$

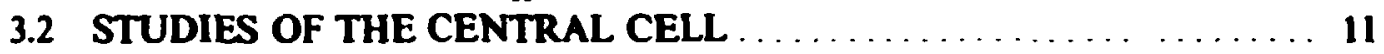

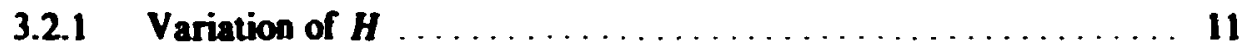

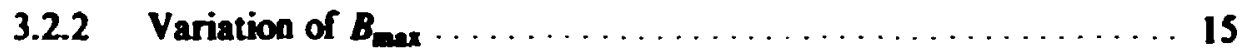

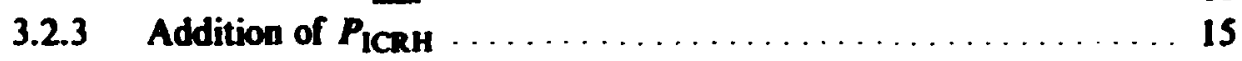

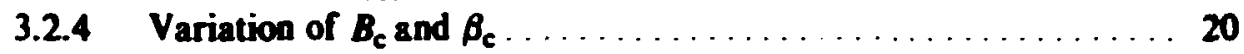

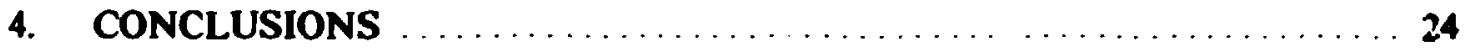

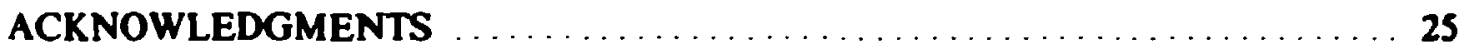

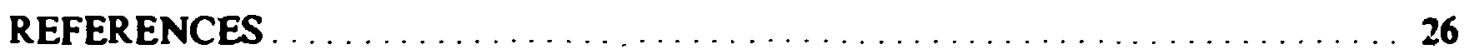

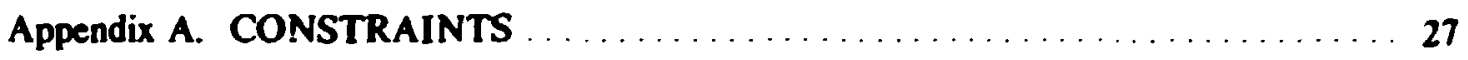

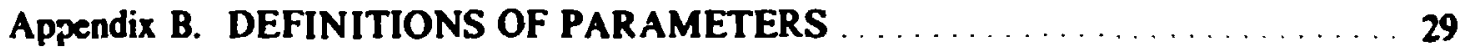




\begin{abstract}
ADSTRACT
Parametric studies are performed using a tandem mirror plasma point model to evaluate the wall loading $\Gamma$ and the physies figure of merit, $Q$ (fusion power/injected power). We explore the relationship among several dominant parameters and determine the impact on the plasma performance of electron cyclotron resonance heating in the plug region.

These global particle and energy balance studies were carried out under the constrzints of magnetohydrodynamic (MHD) equilibrium and stability and constant magnetic flux, assuming a fuxed end-cell geometry.

We found that the higher the choke coil fields, the higher the $Q$, wall loading, and fusion power due to the combination of the increased central-cell field $B_{c}$ and density $n_{c}$ and the reduced central-cell beta $\beta_{c}$ The MHD stability requirement of constant $B_{c}^{2} \beta_{c}$ causes the reduction in $\beta_{c}$. In addition, a higher value of fusion power can also be obtained, at a fixed central-cell length, by operating at a lower value of $B_{c}$ and a higher value of $\boldsymbol{\beta}_{\mathrm{c}}$
\end{abstract}




\section{INTRODUCTION}

Nuclear fusion may become an important energy option in the future because of its readily available fuel and the acceptable environmental and safety aspects of fusion devices.

Magnetic fusion plasma confinement falls into two categories: (1) closed systems, in which the magnetic lines of force close sa themsetves, and (2) open-ended systems, in which they do not. The tokamak concept is the leading example of a closed confinement system; the tandem mirror concept is the leading example of an open-ended confinement system.

The tandem mirror concept evolved from the simple mirror cell shown in Fig. I(a). The simple geometry is subject to magnetohydrodynemic (MHD) instabilitien, however, which can result in a rapid loss of plasma from the system. To stabilize the configuration, the minimum-B mirror cell, shown in Fig. 1(b), was developed. This arrangement leads to the formation of a magnetic well in which the magnetic field induction $B$ increases in every direction from the center. Even with gross MHD stability, some plasma is still lost out the ends of the nirror cell due to the collisional scattering of particles into the loss cone. Studies' have shown that a single-mirror-cell reactor can only achieve slightly more power than it ionsumes $(Q \sim 1)$.

In late 1976, Dimov and Fowler and Logan ${ }^{3}$ realized the benefit of connecting two mirror cells by a cylindrical region with a solenoidal magnetic field. They independently proposed the tandem mirror concept shown in Fig. I(c). Detailed reactor studies of the first tandem mirror yielded a predicted $Q-5$ (ref. 4).

In order to lower the high-energy neutral beam requirements for sustaining the endplug plasma, Baldwin and Logan proposed the "thermal barrier" concept ${ }^{5}$ in which the plug electron temperature is raised above that of the central-cell electrons, thus thermally isolating the two electron species.

This tandem mirror thermal barrier concept uses a region of minimum electrostatic potential that confines the electrons but ejects lowenergy ions. Because of the high thermal velocity of the electrons, thei: emperature $T_{\propto}$ is normally uniform along the magnetic field lines. However, if potential valleys can be established between the central cell and the end plugs, lien electron fluw can the impeded. It is, therefore, possible to use microwave heating in the plugs to make the plug electron temperature $r_{\text {ep }}$ much greater than the central-cell electron temperature, $T_{e c}$. As a consequence, high values of $T_{e p}$ will provide a larger central-cell potential $\phi_{c}$ without requiring a high end-plug density $n_{p}$. Also, the reduced plug pressure reduces the required magnetic field and neutral beam injection energy in the er:d plugs. Analyses of reactor designs using the thermal barrier concept have yielded $Q-20-30$ (ref. 6).

Figure 2 illustrates the different axial profiles for magnetic field, plasma potential, and plasma density found in a tandem mirror with and without thermal barriers. An example of a tandem mirror reactor (TMR) with thermal barriers is the coniguration examined during the Lawrence Livermore National Laboratory (LLNL) Mirror Advanced Reactor Study (MARS), ${ }^{7}$ which is shown in Fig. 3. 


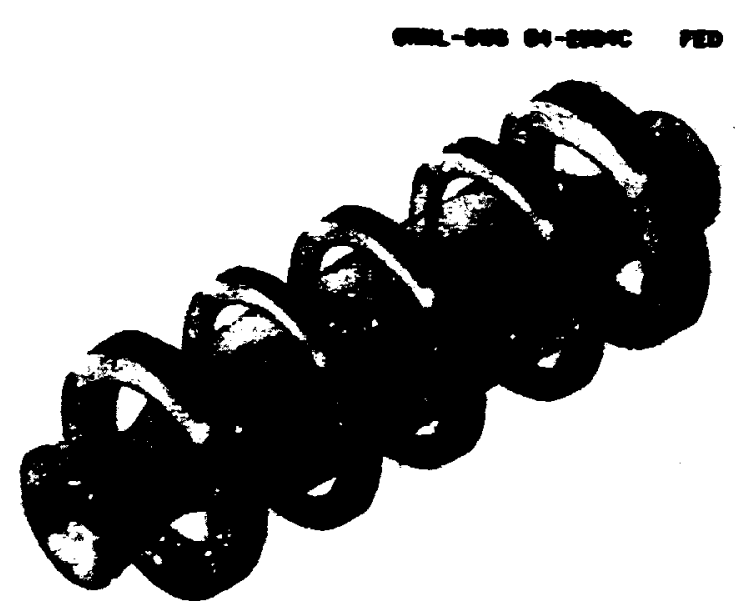

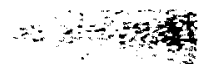

. 5

$\cdots$

$\because \frac{\pi}{8}$

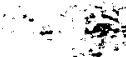

$\therefore$ :

$\therefore+4$

thes

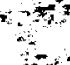

(6) sample manon

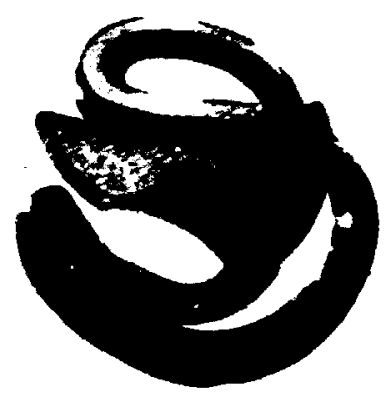

(b) minnum-s manon

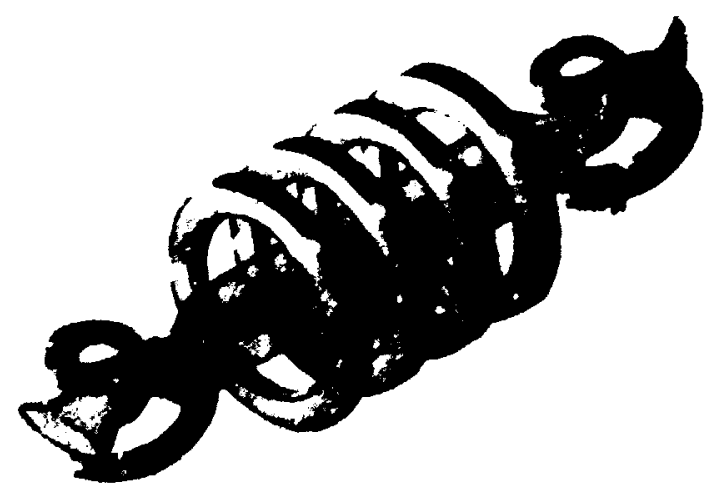

(e) Tanodu munon

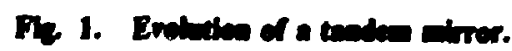


ORNL-DWG 84-2585 FED
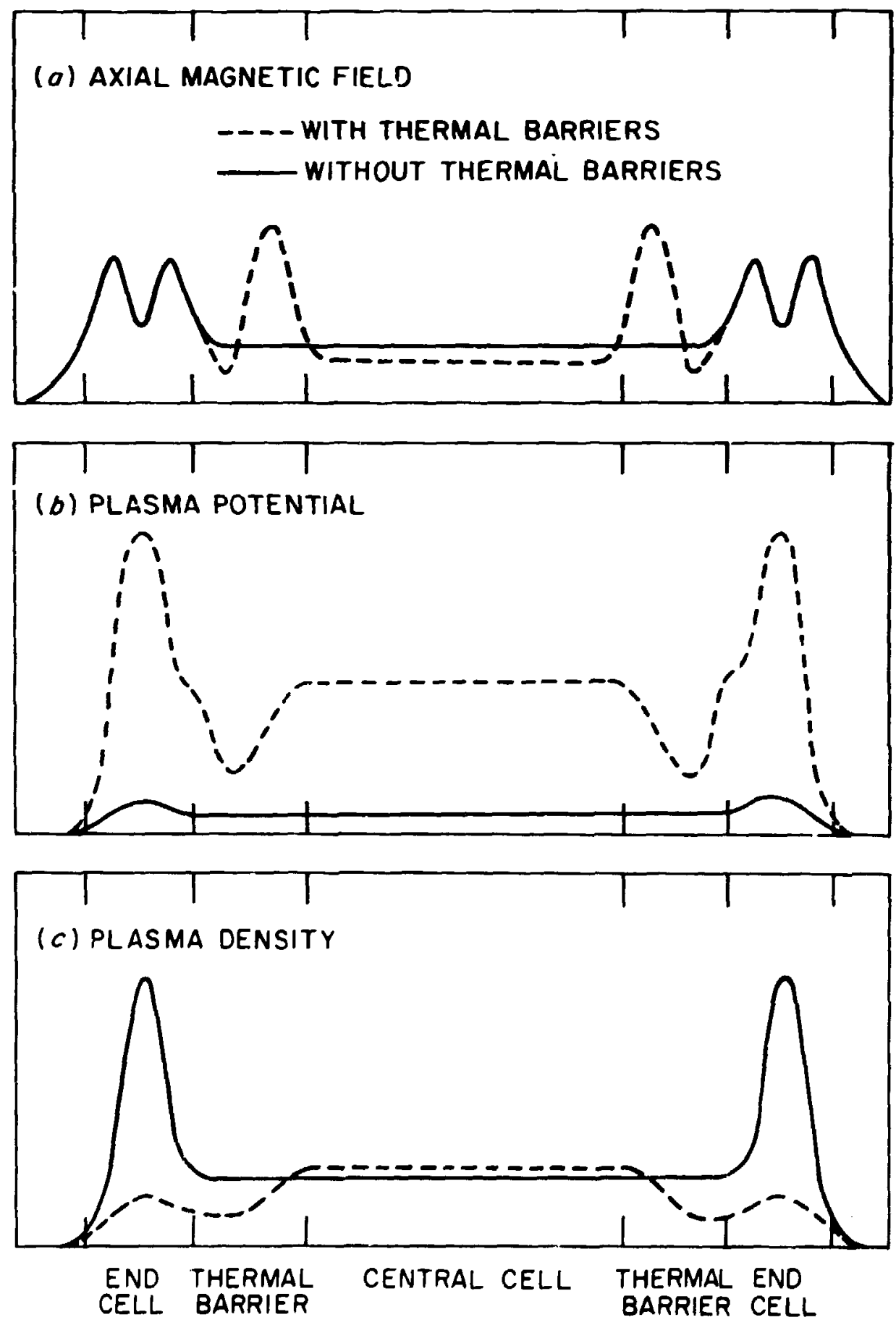

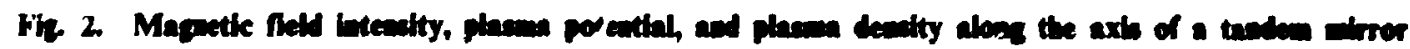
systew with and without ane type of thranai iarres. 


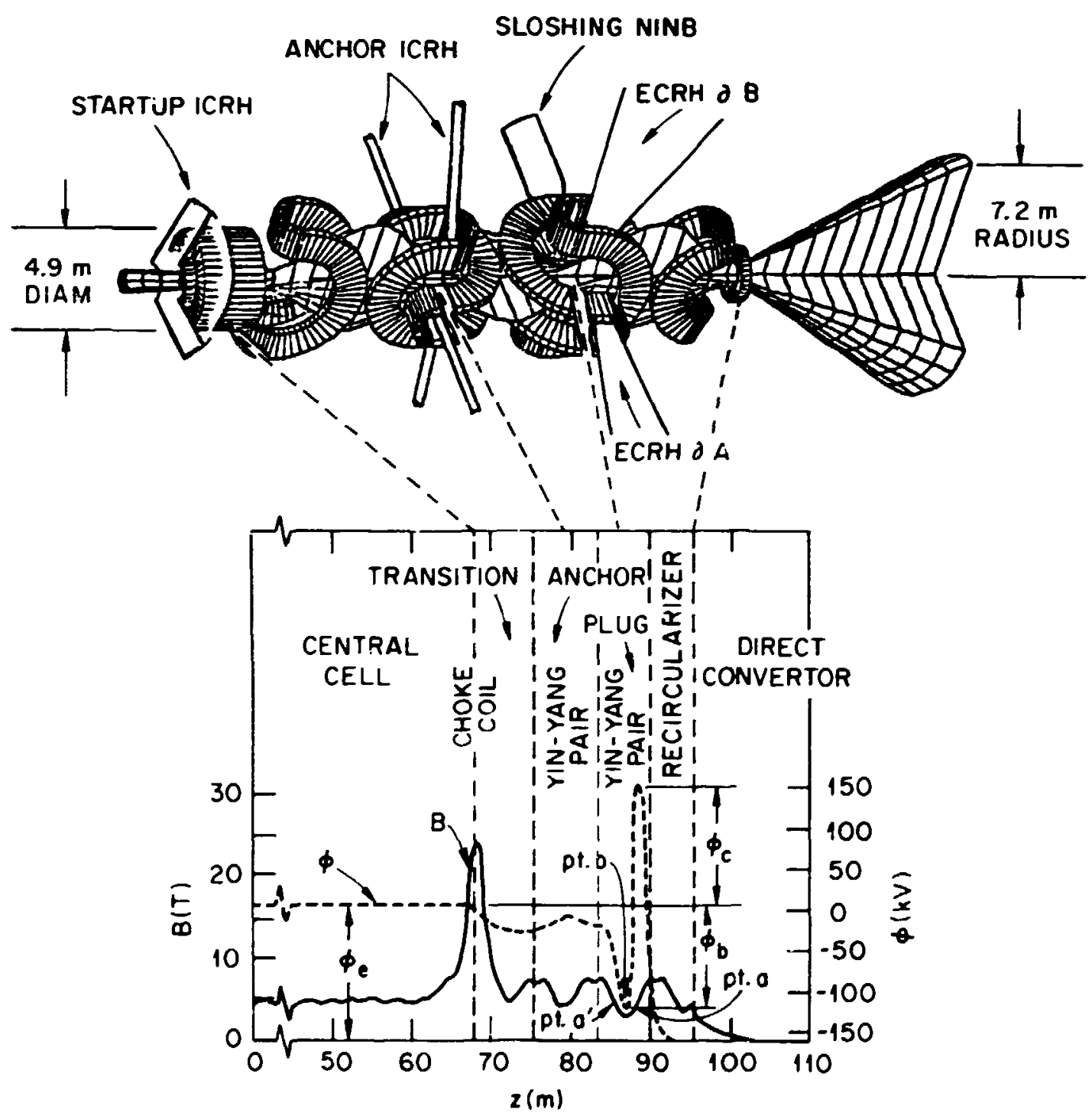

Fig. 3. MARS proflea. 


\section{APPROACH}

With MARS as a basis, a number of prominent physics and engineering parameters of a TMR with thermal barriers were examined using the global energy and particle balance code TMRBAR. ${ }^{8}$ The physics constraints applied to these analyses are given in Appendix A; parameters are defined in Appendix B.

The equations solved by the TMRBAR code include particle and energy balances for the central-cell and end-cell species, quasi neutrality, and potentials and temperatures at cardinal points for a set of given power outputs and field profiles.

The cardinal points chosen for MARS-like mirror fusion reactors are indicated in Fig. 4 and include the central sll, the transition region, the geodesic curvature peak, the anchor inner and outer mirrors, the anchor midplane, the plug inner and outer mirrors, the plug midplane, and the sloshing ion injection points.

For a given set of input, TMRBAR calculates the steady-state plasma conditions for a TMR. Key parameters supplied to TMRBAR include (1) the magnetic fields and beta values at the cardinal points; (2) the desired fusion power output; (3) the length of the central cell, transition region, anchor, and plug; (4) the alpha paiticle concentration in the central cell; (5) the ratios of trapped to passing ion dersity, and (6) initial guesses of temperature and potentials. Most of the input parameters are dependent on one another because they must adherc not only to the physics constraints given in Appendix $A$ but also to the restriction of a fixed configuration. For example, as the value of the trapped ion current ratio $\boldsymbol{H}$ is increased at constant fusion power, the magnetic field and beta values in the central cell must be adjusted accordingly, due to the increase in the trapping current. Likewise, if the choke coil field $B_{\max }$ is varied, then the central-cell values of magnetic field and beta, as well as the fusion power, must be changed simultaneously to satisfy the constraint of constant magnetic flux.

In Sect. 3, the sensitivity of key physics and engineering quantities to various configurational and operational changes is examined via parametric analysis. The results presented show not only the behavior of the two figures of merit, $Q$ and $\Gamma$, but also the interdependence of several important tandem mirror parameters. The results are given for parametric analyses of the central cell and of the plug region.

For the plug region, studies were made on the effects of varying the piug magnetic field $B_{\mathrm{b}}$ and beta $\beta_{\mathrm{b}}, B_{\mathrm{b}}$ alone, the density fraction of central-cell electrons at the plug $F_{\mathrm{oc}}$, and the ratio of passing and trapped ions to passing ions at the plug, 8 . For the central cell, studies were made on the effects oi varying the coil field $B_{\max }$, the ion cyclotron resonance heating (ICRH) power $\boldsymbol{P}_{\text {ICRH, }}$, the ratio of trapped ion current given by FokkerPlanck calculations to that given by the Futch-LoDestro square-well calculation $H$, and the central-cell magnetic field $B_{c}$ and beta $\beta_{c}$. Also included is the impact of applying Shearer's electron cyclotron resonance heating (ECRH) power requirement calculation formula ${ }^{9}$ to the central-cell parametric analyses. The difference between the original algorithm for computing the loss term of the hot electron power balance equation ${ }^{10}$ and Shearer's algorithm is that the latter treats scattering, orag, and synchrotron radiation losses more completely. As a result, it predicts approximately $40 \%$ higher losses than the original algorithm. 


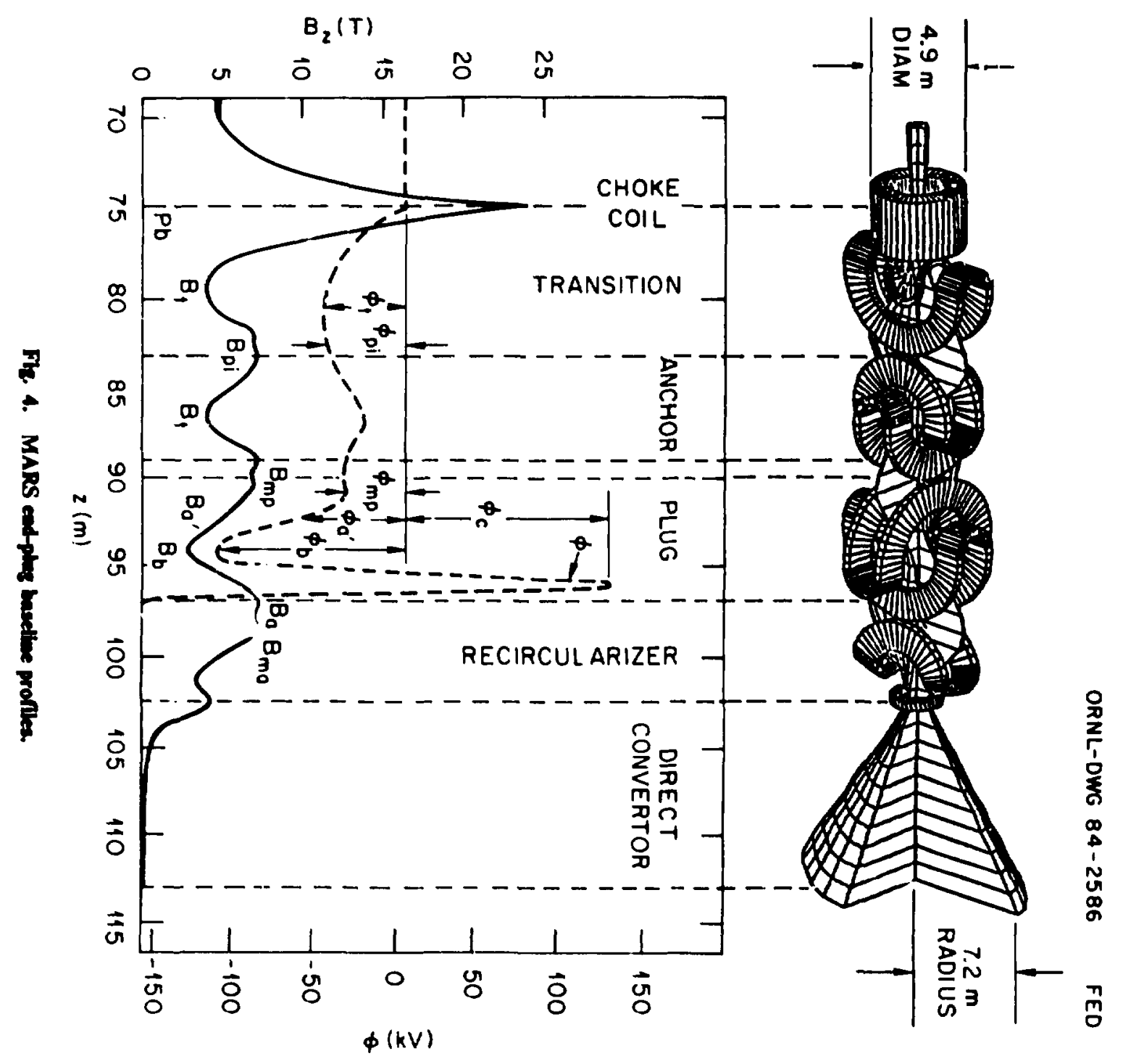

$a$ 


\section{RESULTS}

\subsection{STUDIES OF THE PLUG REGION}

\subsubsection{Variation of $B_{6}$ and $\beta_{6}$}

Because the plug region provides good curvature for a TMR, it is desirable to optimize the plug beta $\beta_{\mathrm{b}}$. Consequently, we first examine the plug magnetic field $\boldsymbol{B}_{\mathrm{b}}$ and $\boldsymbol{\beta}_{\mathrm{b}}$ to determine if an optimum exists under the constraints of constant-beta-corrected $B_{b}$ $\left(B_{b} \sqrt{1-\beta_{b}}=\right.$ const). In carrying out this investigation, we chose to keep the fusion power $P_{\text {fusion, }}$ the $H$ factor, the choke coil field $B_{\max } B_{c}$, and $\beta_{c}$ constant while adjusting the central-cell length $L_{c}$ and the ion and electron temperatures $T_{c}$ and $T_{e c}$ to conform to all constraints under a set of chosen values for $B_{\mathrm{b}}$ and $\beta_{\mathrm{b}}$. Three sets of $B_{\mathrm{b}}$ and $\beta_{\mathrm{b}}$ values were selected for this study (refer to Table 1 ), and the results are detailed in Fig. 5 . Increasing $\beta_{\mathrm{b}}$ by $25 \%$ and $B_{\mathrm{b}}$ by $10 \%$ brings about increases of $36 \%$ in $Q, 6 \%$ in both $L_{c}$ and $T_{c}$, and $3 \%$ in $T_{c e}$. Concomitantly, there is a $34 \%$ decrease in the ECRH power requirements $P_{E C R H}$ and a $7 \%$ decrease in $\Gamma$ resulting from an increase in $T_{c}$ and a decrease in the central-cell ion density $n_{c}$. In general, improved plasma periormance can be obtained at higher values of $B_{\mathrm{b}}$ and $\beta_{\mathrm{b}}$, but no optimum for $B_{\mathrm{b}}$ or $\beta_{\mathrm{b}}$ is observed.

\subsubsection{Variation of $B_{\mathbf{l}}$ Alone}

The eifect of higher values of $B_{b}$ alone on the plarma perforriance is examined here. The input data used for this investigation are similar to those used in the MARS study. Table 2 and Fig. 6 detail the study conditions and results as $B_{\mathrm{b}}$ ranges from 1.5 to about $3 \Gamma$. Among the findings, it is observed that as $B_{b}$ increases, the wall loaoing $\Gamma$ stays essentially unchanged, because of the assumption of fixed $\beta_{\mathrm{c}}$ and $\beta_{\mathrm{b}}$, while $Q$ decreases. The study also reveals that better performance can be obtained by reducing the value of $B_{b}$, which leads to a decrease in the ECRH power requirements. However, when $B_{b}$ is reduced, the spacing between plug mirrors should be changed, and the plasma may not have MHD stability.

\subsubsection{Variation of $g$ and $G$}

With $\beta_{\mathrm{b}}, B_{\mathrm{b}}, B_{\max }, H$, and $L_{\mathrm{c}}$ held constant, the effect of varying $g$ and $G$ is examined. The difference between $G$ (the ratio of sloshing, trapped, and passirg ion density to passing ion density) and $g$ is constrained to be 2.0 (see Table 3 ). In other words, the sloshing ion density is twice as large as the passing ion density in the plug region. Decreases in $\beta_{c}$, the central-cell plasma radius $r_{c}$, and $Q$ result from the decreased value of $g$, as shown in Fig. 7. Figure $7(\mathrm{c})$ is particularly interesting, for it indicates a maximum as well as a minimum. The sensitivity of the ion temperature and $P_{E C R H}$ to variations in $g$ is also shown in Fig. 7.

Figure $7(a)$ indicates that $r_{c}$ decreases as $g$ increases because more ions are trapped in the end-cell region. As expected, for a fixed $P_{\text {fusion }}$ and $L_{c}$, the wall loading $\Gamma$ increases and $r_{c}$ decreases. However, when the desired fusion power output is allowed to fall along with $r_{c}$ due to increased $g$ values, $\Gamma$ decreases because the central-cell ion density $n_{c}$ drops 
Talue 1. Variation of $B_{1}$ and $\beta_{3}$

Constants for this analysis:

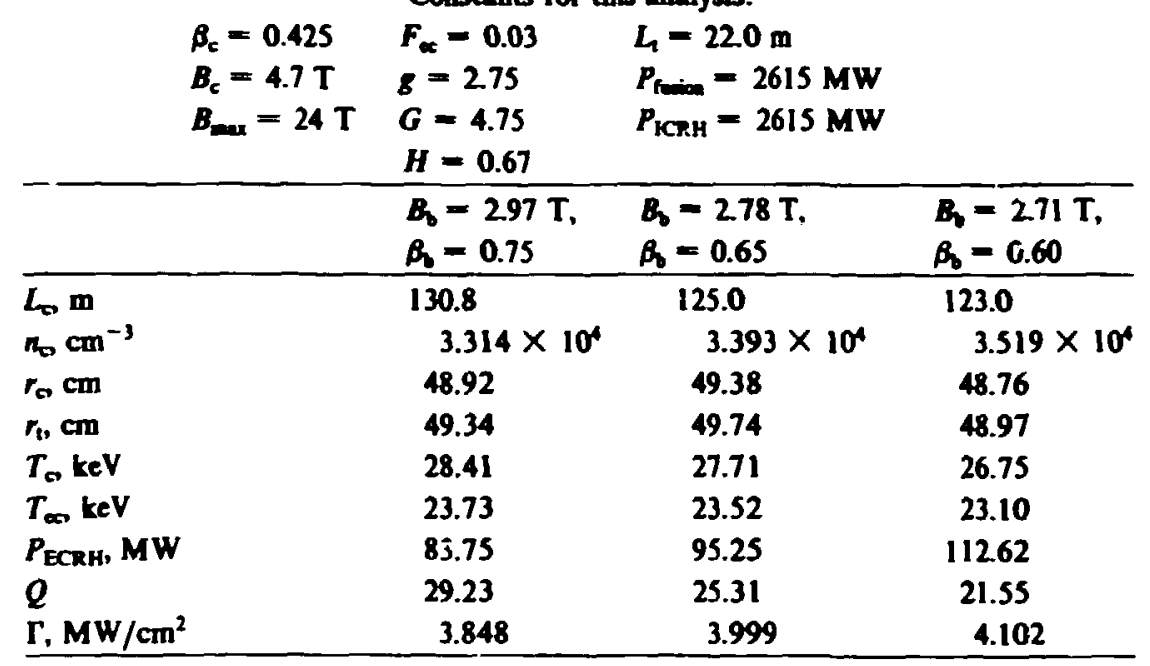
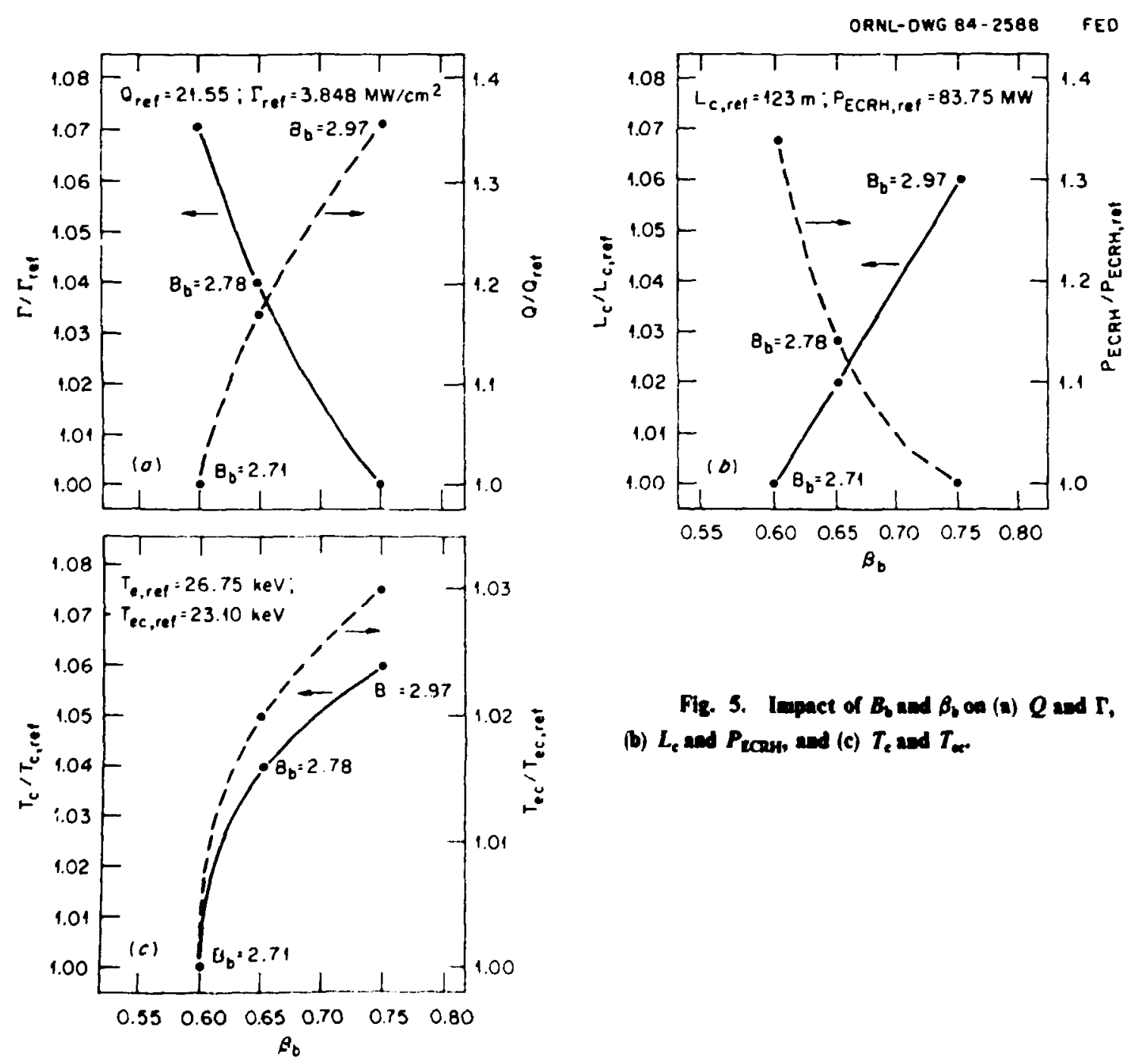

Fig. 5. Inpact of $B_{6}$ and $\beta_{6}$ on (a) $Q$ and $\Gamma$,

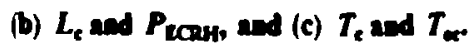


Talie 2 Variation of 8

Constants for this analysis:

\begin{tabular}{|c|c|c|c|c|}
\hline & $\begin{array}{l}B_{c}=0.75 \\
B_{c}=0.425 \\
B_{c}=4.7 \mathrm{~T} \\
B_{\max }=24 \mathrm{~T}\end{array}$ & $\begin{array}{l}F_{\alpha}=0.03 \\
g=2.75 \\
G=4.75\end{array}$ & $\begin{array}{l}H=0.67 \\
L_{1}=22 \mathrm{~m} \\
P_{\text {Iim }}=2615 \% \mathrm{~W} \\
P_{\text {IGA }}=0\end{array}$ & \\
\hline & & $B_{1}=2.97 \mathrm{~T}$ & $B_{1}=2.00 \mathrm{~T}$ & $B_{2}=1.50 \mathrm{~T}$ \\
\hline$\overline{L_{c}, \mathrm{~m}}$ & & 130.8 & 132.4 & 132.4 \\
\hline $\mathrm{n}_{\mathrm{r}} \mathrm{cm}^{-3}$ & & $3.314 \times 10^{4}$ & $3.326 \times 10^{4}$ & $3.301 \times 10^{5}$ \\
\hline$r_{c} \mathrm{~cm}$ & & 48.92 & 48.51 & 45.72 \\
\hline$r_{t}, \mathrm{~cm}$ & & 49.34 & 48.92 & 49.17 \\
\hline$T_{c}, \mathrm{keV}$ & & 28.41 & 28.31 & 28.51 \\
\hline$T_{\infty}, \mathrm{keV}$ & & 23.73 & 23.64 & 23.77 \\
\hline$f_{\mathrm{ECRH}} \cdot \mathrm{MW}$ & & 83.75 & 48.90 & 40.97 \\
\hline$Q$ & & 29.23 & 58.24 & 64.91 \\
\hline $\mathrm{r}, \mathrm{MW} / \mathrm{cm}^{2}$ & & 3.848 & 3.825 & 3.813 \\
\hline
\end{tabular}

ORNL-DWG 84-2589 FED

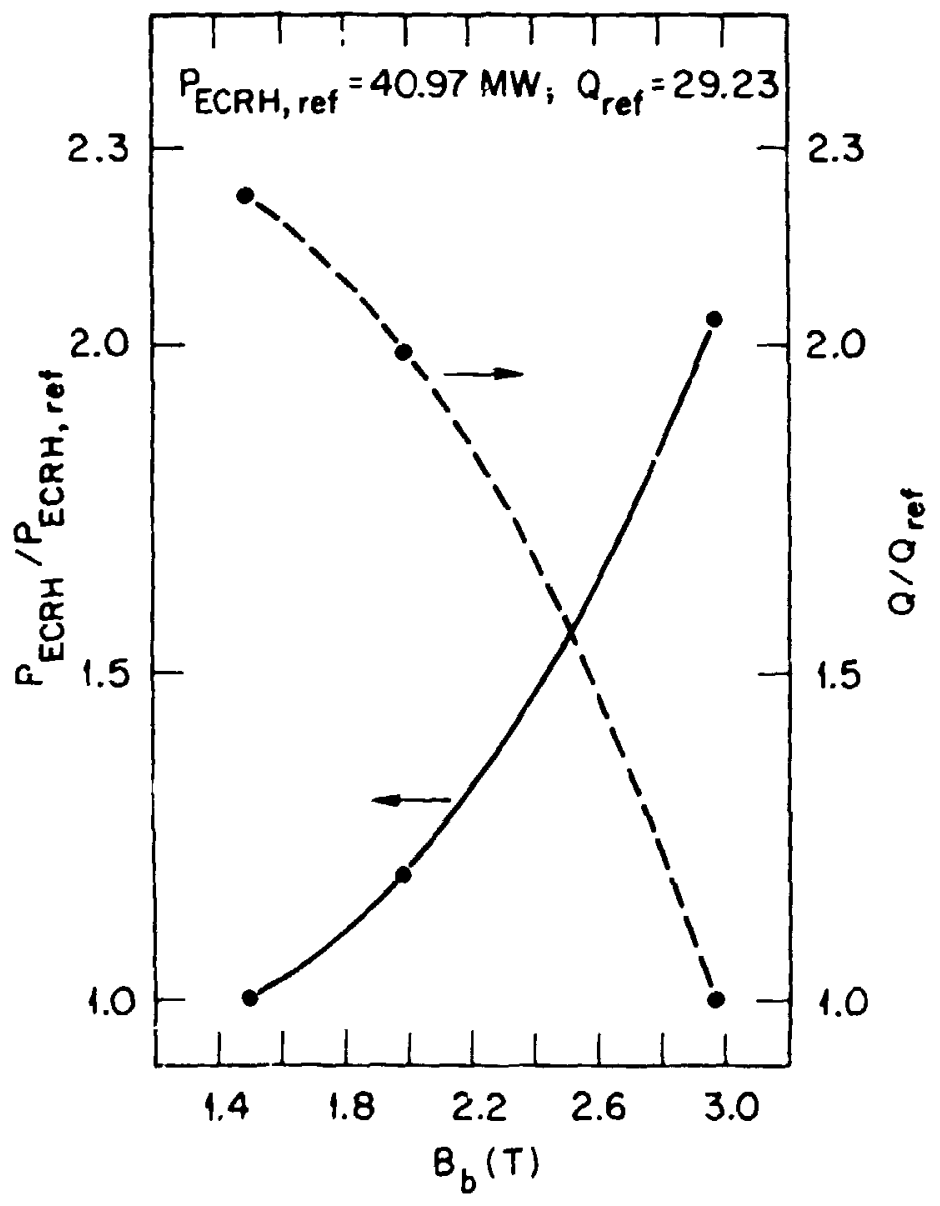

Fig. 6. Impact of $B_{h}$ on $P_{\text {ECan }}$ and $Q$. 
Table 3. Variation of $g$ and $G$

Constants for this acalysis:

\begin{tabular}{|c|c|c|c|c|}
\hline & $\begin{array}{l}\beta_{\mathrm{c}}=0.75 \\
B_{\mathrm{c}}=2.97 \mathrm{~T} \\
B_{\mathrm{m}}=24 \mathrm{~T}\end{array}$ & $\begin{array}{l}F_{\mathrm{oc}}=0.03 \\
H=0.67\end{array}$ & $\begin{array}{l}L_{c}=130.8 \mathrm{~m} \\
L_{L}=22 \mathrm{~m} \\
P_{\mathrm{ICOH}}=0\end{array}$ & \\
\hline & & $\begin{array}{l}g=2.0, \\
G=4.0\end{array}$ & $\begin{array}{l}g=2.75 \\
G=4.75\end{array}$ & $\begin{array}{l}g=3.5 \\
G=5.5\end{array}$ \\
\hline$P_{\text {finin }}, M W$ & & 2615 & 2615 & 1150 \\
\hline $\mathrm{n}_{6} \mathrm{~cm}^{-j}$ & & $3.174 \times 10^{4}$ & $3.550 \times 10^{4}$ & $2.405 \times 10^{4}$ \\
\hline$r_{0} \mathrm{~cm}$ & & 50.28 & 46.98 & 44.12 \\
\hline$r_{1}, \mathrm{~cm}$ & & 46.88 & 47.39 & 47.65 \\
\hline$T_{c}, \mathrm{keV}$ & & 29.53 & 26.62 & 29.33 \\
\hline$T_{\infty}, \mathrm{keV}$ & & 24.32 & 22.84 & 24.67 \\
\hline$\beta_{c}$ & & 0.522 & 0.425 & J.276 \\
\hline $\boldsymbol{B}_{\mathrm{f}} \mathbf{T}$ & & 4.24 & 4.70 & 5.05 \\
\hline$P_{\text {ECRH }}, \mathrm{MW}$ & & 108.0 & 135.8 & 119.4 \\
\hline$Q$ & & 23.06 & 18.57 & 9.39 \\
\hline$\Gamma, \mathrm{MW} / \mathrm{cm}^{2}$ & & 3.669 & 3.964 & 1.861 \\
\hline
\end{tabular}
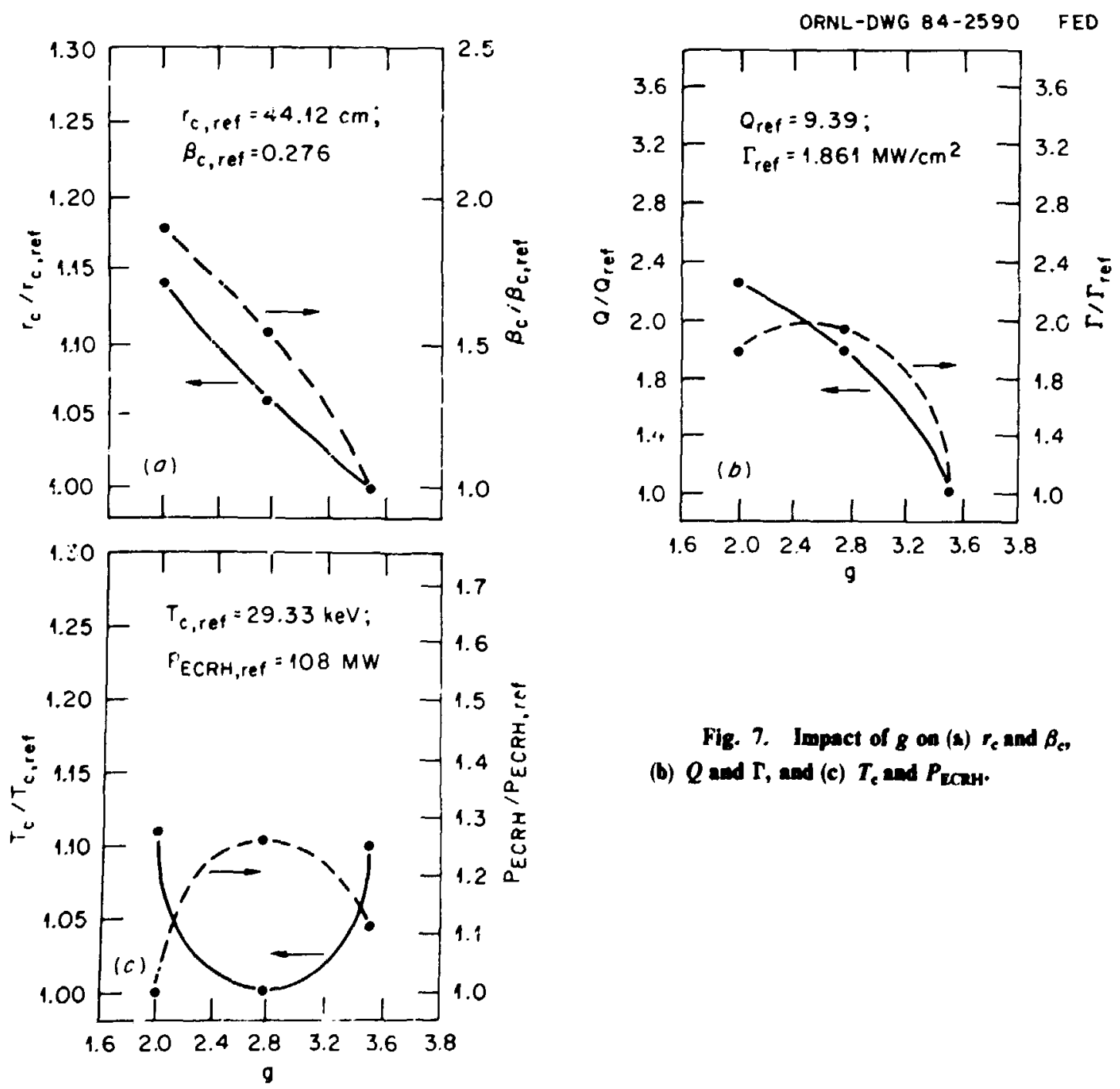

Fig. 7. Impact of $g$ an $(a) r_{c}$ and $\beta_{c}$, (b) $Q$ and $\Gamma$, and (c) $T_{c}$ and $P_{\mathrm{ECOH}}$. 
sharply. Despite the large reduction in $P_{\text {fusion }}$ (by $1465 \mathrm{MW}$ ), $P_{E C R H}$ decreased only 16.4 MW. The continued need for almost $120 \mathrm{MW}$ of ECRH power explains why the $Q$ value decreases monotonically with increasing $g$ values. Of particular interest are the local maximum and minimum values exhibited by $P_{\text {ECRH }}$ and $T_{\mathrm{c}}$. This behavior may be partially caused by the large drops in both $P_{\text {fusion }}$ and $\beta_{c}$ which result from satisfying the constraints of Appendix A. As a whole, the findings indicate an improvement in plasma performance with decreasing $g$ for $g>2$.

\subsubsection{Study of $F_{\text {ec }}$}

The fourth end-cell parametric analysis focuses on $F_{\infty c}$ an important parameter used by TMRBAR to compute the requiren microwave power for sustaining the hot electrons. In this study, the central-cell temperatures $T_{\mathrm{c}}$ and $T_{\mathrm{ec}}$, field $B_{\mathrm{s}}$, and $\beta_{\mathrm{c}}$ (in addition to $F_{\mathrm{ec}}$ ) were allowed to change while $P_{\text {fusion, }}, L_{c}$, and $B_{\max }$ were held constant. Parameters are tabulated in Table 4. Figure 8 shows that the ECRH power requirements increase along with $F_{\text {ec. }}$. This leads to a decrease in $Q$ by $8 \%$ as $F_{\text {ec }}$ increases from 0.01 to 0.04 . From these results, we may conclude that the lower the $F_{e c}$ value, the better the performance will be.

\subsection{STUDIES OF THE CENTRAL CELL}

The impact on tandem mirror performance of variations in $H, B_{\max }, B_{s}$, and $\boldsymbol{\beta}_{\mathrm{c}}$ is refurted here. Also included in the discussions is the influence on performance of J. Shearer's ECRH formulation, ${ }^{9}$ which takes into account losses about $40 \%$ higher than those assumed for the Mirror Fusion Test Facility (MFTF-B). ${ }^{10}$

\subsubsection{Variation of $\boldsymbol{H}$}

Investigations of the effect of varying $H$ included three studies. First, the $H$ value was varied from 0.63 to 0.83 with Shearer's formulation included. Table 5 and Fig. 9 summarize the findings. During this study, the $H$ value, $P_{\text {fusion }}, T_{c}$, and $T_{e c}$ were varied simultaneously while $L_{c}, B_{c}, \beta_{c}$, and $B_{\max }$ wers held constant. Increasing $H$ from 0.63 to 0.83 lowered the two figures of merit, $Q$ and $\Gamma$, by $23 \%$ and $45 \%$, respectively. This is the result of a large decrease in $\boldsymbol{P}_{\text {fusion }}$ and a relatively smaller reduction in $\boldsymbol{P}_{\text {ECRH }}$. The central-cell temperatures $T_{\mathrm{c}}$ and $T_{\mathrm{ec}}$ were found to increase with $H$ (see [Fig. 9(c)], while $P_{\text {fusion }}$ and the central-cell ion density decreased.

Second, the values of $P_{\text {fusion, }}, L_{c}$, and $B_{\max }$ were fixed, while $H, T_{c}, T_{c c}, B_{c}$, and $\beta_{c}$ were allowed to vary. Results are given in Table 6 and Fig. 10. The increase in $H$ causes a decrease in $\beta_{c}, T_{c}$, and $r_{c}$ and a subsequent increase in $\Gamma$. The decline in central-cell temperature and plasma radius is responsible for the reduction in $\beta_{\mathfrak{c}}$ [see Fig. 10(a)] and the increase in $\Gamma$ [see Fig. 10(b)], respectively. Hence, it is advantageous to operate a TMR at lower $H$ values if possible.

Third, values of $H$ ranging from 0.9 to 2.0 were considered. The $H$ factor corrects for the effects of the magnetic and notential profiles, as well as the treatment of multiple 


\begin{tabular}{|c|c|c|c|c|}
\hline & \multirow[t]{2}{*}{$\begin{array}{l}\beta_{h}=0.75 \\
B_{b}=2.97 \mathrm{~T} \\
B_{\max }=24 \mathrm{~T}\end{array}$} & $\begin{array}{l}\text { Constants for thi } \\
g=2.75 \\
G=4.75 \\
H=0.67 \\
L_{\varepsilon}=136.8 \mathrm{~m}\end{array}$ & $\begin{array}{l}\text { analysis: } \\
L_{\mathrm{L}}=220 \mathrm{~m} \\
P_{\mathrm{f}}=2615 \mathrm{MW} \\
P_{\mathrm{ICOH}}=0\end{array}$ & \\
\hline & & $F_{\alpha x}=0.01$ & $F_{\alpha c}=0.03$ & $F_{\alpha}=0.04$ \\
\hline $\mathrm{mocm}^{-3}$ & & $3.563 \times 10^{4}$ & $3.550 \times 10^{4}$ & $3.574 \times 10^{4}$ \\
\hline$r_{c}, \mathrm{~cm}$ & & 46.97 & 46.98 & 46.81 \\
\hline$r_{1}, \mathrm{~cm}$ & & 46.70 & 47.39 & 47.21 \\
\hline$T_{0} \mathrm{keV}$ & & 26.42 & 26.62 & 26.43 \\
\hline$T_{\infty}, \mathrm{keV}$ & & $22.7 !$ & 22.84 & 22.74 \\
\hline$\beta_{c}$ & & 0.443 & 0.425 & 0.425 \\
\hline$B_{\mathrm{c}}, \mathrm{T}$ & & 4.60 & 4.70 & 4.70 \\
\hline$P_{\text {ECRH }}, \mathrm{MW}$ & & 127.8 & 135.8 & 138.3 \\
\hline$Q$ & & 19.72 & 18.75 & 18.25 \\
\hline$\Gamma, \mathrm{MW} / \mathrm{cm}^{2}$ & & 3.942 & 3.964 & 3.974 \\
\hline
\end{tabular}

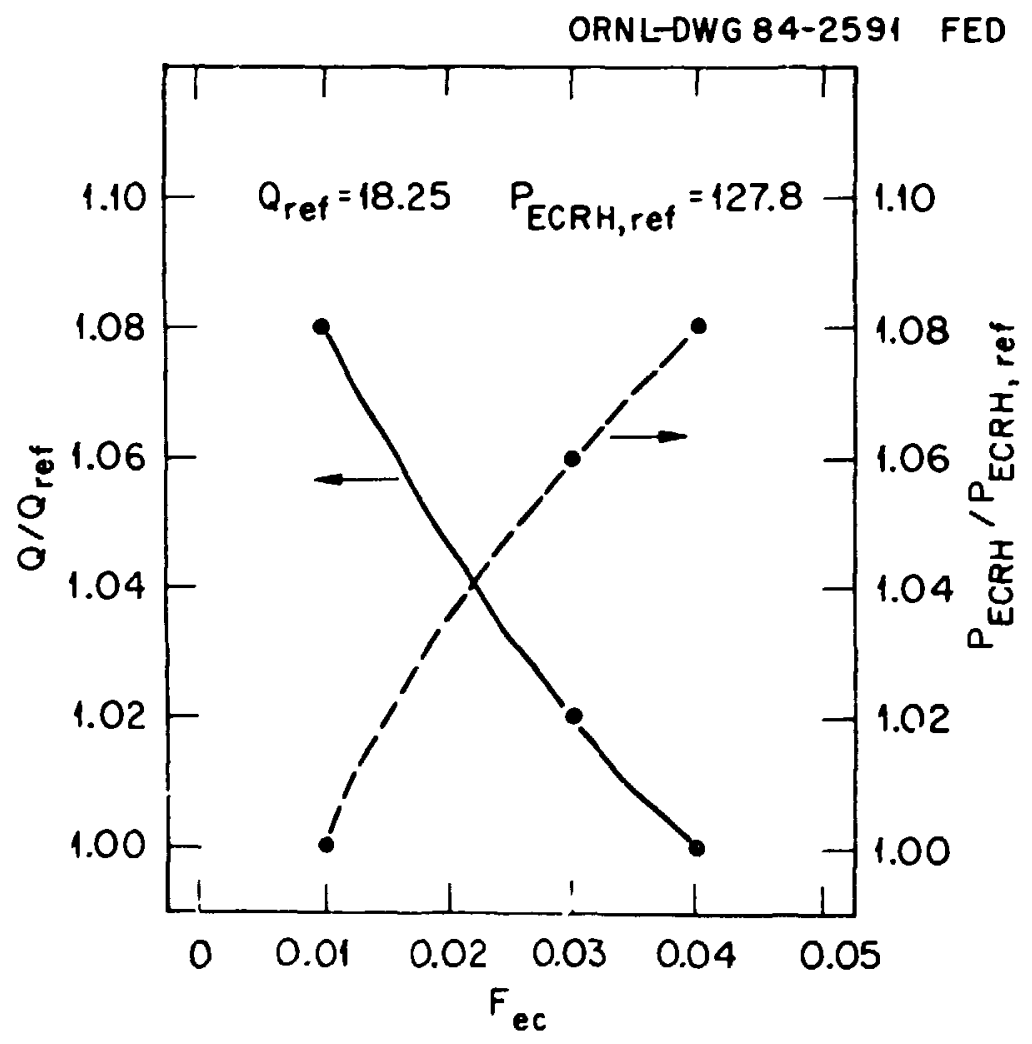

Fig. 8. Impact of $f_{\alpha}$ on $Q$ and $P_{\text {ECRH. }}$ 
Talle 5. Vertation of $H$ ains Shearer's ECRH power calcatation enthod (vartallte facion power)

Constants for this analysis:

\begin{tabular}{|c|c|c|c|c|c|c|}
\hline & \multirow[t]{2}{*}{$\begin{array}{l}\beta_{b}=0.75 \\
\beta_{c}=0.425 \\
B_{b}=2.97 \mathrm{~T}\end{array}$} & \multicolumn{2}{|c|}{$\begin{array}{l}B_{\mathrm{c}}=4.7 \mathrm{~T} \\
B_{\max }=24 \mathrm{~T} \\
2_{\alpha}=0.03 \\
g=2.75\end{array}$} & \multicolumn{2}{|c|}{$\begin{array}{l}L_{c}=130.8 \mathrm{~m} \\
L_{h}=22.0 \mathrm{~m} \\
P_{\mathrm{lCRh}}=0\end{array}$} & \multirow[b]{2}{*}{$1 / H=1.6$} \\
\hline & & $=1.2$ & $1 / H$ & $=1.4$ & $1 / H=1.5$ & \\
\hline$P_{\text {fmion, }}, \mathrm{MW}$ & 1925 & & 2370 & & 2615 & 2810 \\
\hline$T_{n} \mathrm{keV}$ & 33.83 & & 28.51 & & 26.62 & 25.29 \\
\hline$T_{\infty}, \mathrm{keV}$ & 26.88 & & 23.99 & & 22.8\% & 22.08 \\
\hline$n_{0} \mathrm{~cm}^{-3}$ & 2.77 & $1 \times 10^{4}$ & 3.29 & $92 \times 10^{4}$ & $3.550 \times 10^{4}$ & $3.740 \times 10^{4}$ \\
\hline$r_{\mathrm{c}} \mathrm{cm}$ & 47.16 & & 46.82 & & 46.98 & 47.37 \\
\hline$r_{1}, \mathrm{~cm}$ & 47.48 & & 47.22 & & 47.39 & 47.79 \\
\hline$P_{\text {ECRH. }}, M W$ & 118.6 & & 127.4 & & 135.8 & 144.3 \\
\hline$Q$ & 15.32 & & 17.87 & & 18.57 & 18.82 \\
\hline Г. $\mathrm{MW} / \mathrm{cm}^{2}$ & 2.91 & & 3.60 & & 3.964 & 4.234 \\
\hline
\end{tabular}
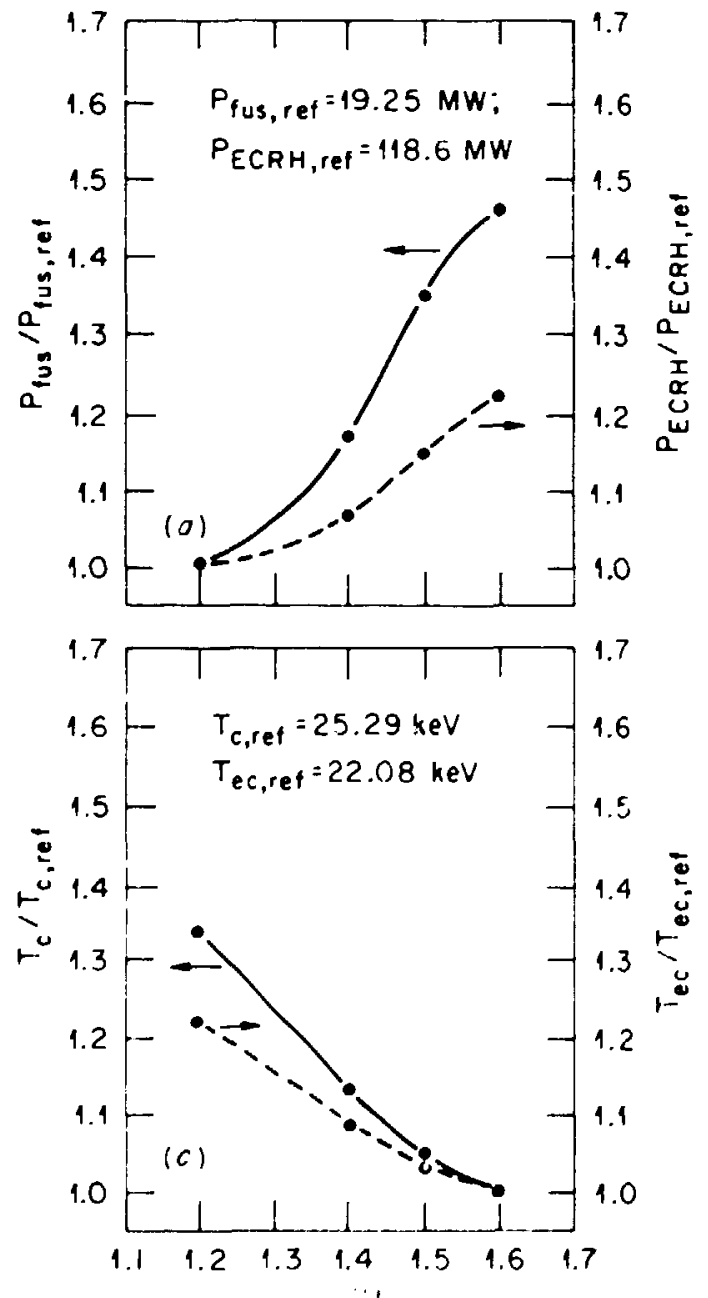

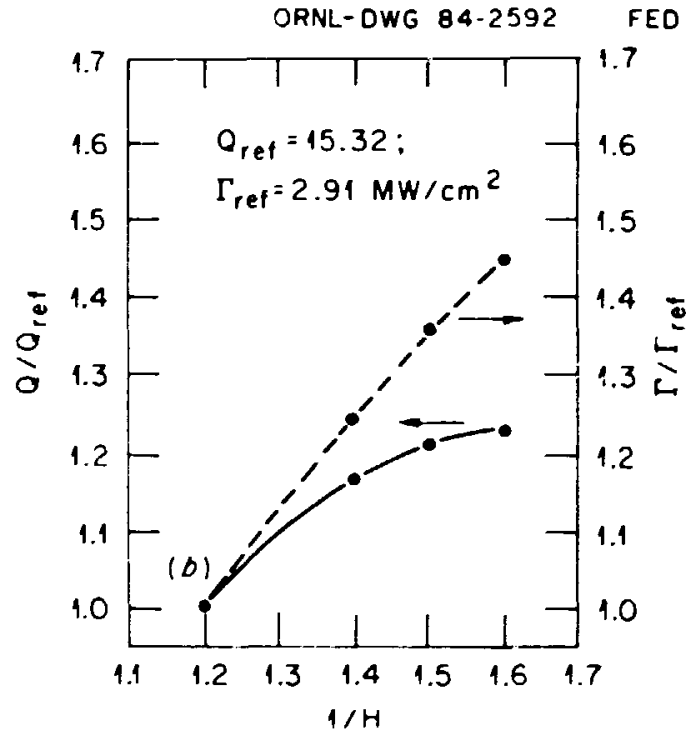

Fig. 9. Impact of $H$ on (a) $P_{\text {tran }}$ and $P_{\text {zonh, }}$ (b) $Q$ and $\Gamma$, and (c) $T$, and $P_{\mathrm{zc} a r}$ with varlable fuslon power. 
Talle 6. Vartation of $\boldsymbol{H}$ with fred feder poner

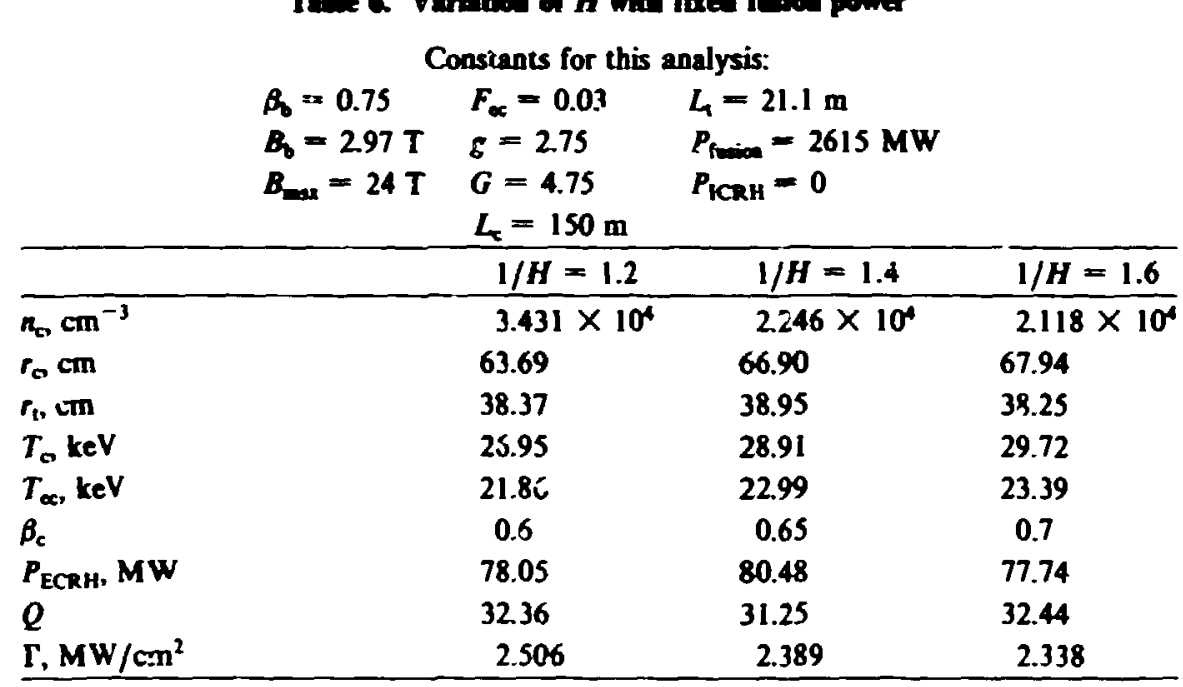
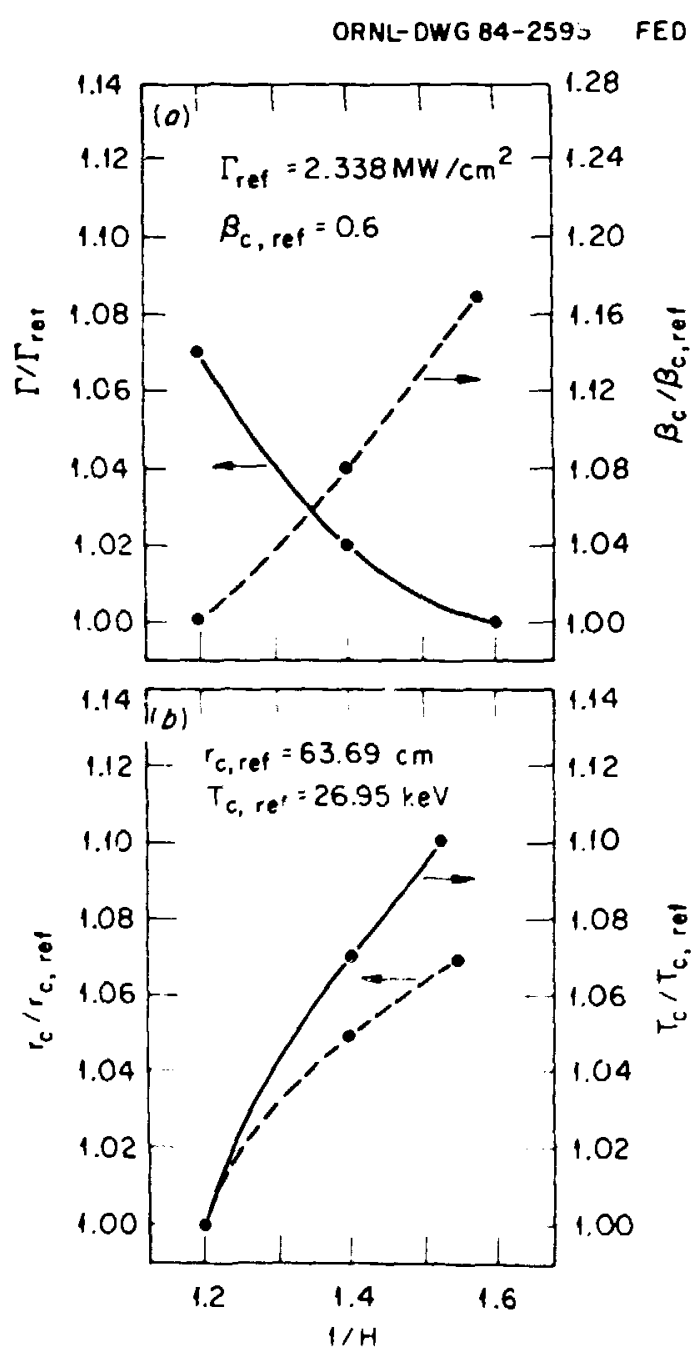

Fi. 10. Inpact of $H$ on (a) $\Gamma$ and $B_{e}$ and (b) $r_{c}$ end $T_{e}$ with $n x e d$ fucton power and $L_{e}$. 
trapped ion distributions. Before the physics freeze or MARS in December 1982, rreliminary estimates obtained by LLNL suggested a trapped ion ratio of $H=2 / 3$ for the MARS baseline. More recent estimates by Devoto ${ }^{11}$ indicate that the values of $H$ should be corrected to around 1.5. We may conclude from Table 7 and Fig. 11 that the lower the $H$ value, the better the performance. These results are consistent with the . Indings of the two preceding studies. We cannot, however, legislate the value of $H$ since it is a property of the magnetic field and porential profile, as well as the ratio of trapped-ion to passing ion density.

\subsubsection{Variation of $B_{\text {max }}$}

Magnetic potentials created by magnetic field profiles are responsible for plasma wnfinement in a tandem mirror device. Consequently, the highest magnetic field of a tandem mirror device, the choke coil field $\boldsymbol{B}_{\max }$, affects the potential profile profoundly. Because of the dominant nature of this parameter, it is of great importance to understand how reactor performance is affected by variations in $B_{\max }$. Two studies were performed. The first concentrated on the variation of $B_{\max }$. The second took into account the effects of increased losses in estimating the ECRH power requirements.

The results of the first stucy are summarized in Table 8 and Fig. 12; those of the second study are detailed in Table 9 and Fig. 13. It should be noted that the global cnergy balance constraint (Appendix $A$ ) requires that $B_{\max }, B_{c}$, and $\beta_{c}$ be changed simultaneously. The results of both studies indicate that increasing $\boldsymbol{B}_{\max }$ increases $\boldsymbol{B}_{\mathrm{c}}, \boldsymbol{P}_{\text {fusion, }}$ $P_{\text {ECRH }}, \Gamma$, and $Q$ but reduces $\beta_{c}, T_{c}$, and $r_{c}$. The increase in the magnetic pressure results in the decrease in $\beta_{\mathrm{c}}$. Furthermore, due to the MHD stability requirement $\left(B_{c}^{2} \beta_{c}=\right.$ const) and the principle of conservation of magnetic flux, the value of $B_{c}$ increases while the central-cell radius $r_{c}$ decreases. Hence, as $P_{\text {fusion }}$ increases, the wall loading increases accordingly. Although both $\boldsymbol{P}_{\text {fusion }}$ and and $\boldsymbol{P}_{\text {ECRH }}$ increase with $\boldsymbol{B}_{\max }$, the difference in their magnitudes results in better plasma performance at higher values of $B_{\max }$. The incorporation of enhanced drag losses in the plug electron mwer balance leads to higher ECRH power requirements and a subsequent sizable reduction of $Q$ (from 29.16 to 18.57 ), as shown in Tables 8 and 9.

\subsubsection{Addition of $\boldsymbol{P}_{\mathbf{I C R H}}$}

The addition of ICRH power to the central cell can also lead to a number of plasma performance changes. We addressed the effect on performance due to the addition of

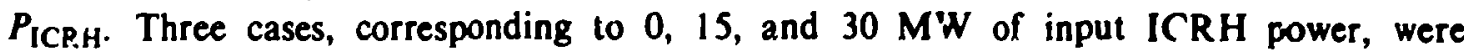
investigated; the results are tabulated in Table 10 and plotts 1 in Fig. 14. In Table 10 and Fig. 14(c), it is observed that adding ICRH power to the central-cell ions leads to a substantial increase in $\boldsymbol{P}_{\text {fusion }}$ and $\Gamma$, accompanied by slightly reduced operating temperatures in the central cell. However, as can be seen from Table $10, P_{E-R H}$ increases monotonically with $P_{\mathrm{ICRH}}$. This effect is expected because at fixed $B_{\mathrm{b}}$ and $\beta_{\mathrm{b}}$ more ECRH power is needed to sustain the end cell as the central-cell temperatures decrease. Because of the comparable increases in both $P_{E C R H}$ and $P_{\text {fusion, }}$ the $Q$ value suffers a moderate decrease of $13 \%$ with the addition of $30 \mathrm{MW}$ of ICRH power. There may be a further reduction in

performance, depending on the particular ECRH model used. With increased drag losses 
Trlue 7. Variation of $A$ with fixed fuble power ases $\leqslant \leqslant 20$

Constants for this analysis:

\begin{tabular}{|c|c|c|c|c|}
\hline & $\begin{array}{l}\beta_{b}=0.75 \\
\beta_{c}=0.89 \\
B_{b}=2.97 \mathrm{~T} \\
B_{c}=3.25 \mathrm{~T}\end{array}$ & $\begin{array}{l}B_{m e x}=24 T \\
F_{\alpha c}=0.03 \\
g=2.75\end{array}$ & $\begin{array}{l}G=4.75 \\
L_{4}=22 \mathrm{~m} \\
P_{\text {fuion }}=2615 \mathrm{M} \\
P_{\mathrm{ICAH}}=0\end{array}$ & \\
\hline & & $H=1 / 1.1$ & $H=1.54$ & $H=2.0$ \\
\hline$L_{n} \mathrm{~m}$ & & 108.0 & 150.0 & 175.0 \\
\hline$n_{0} \mathrm{~cm}^{-3}$ & & $3.736 \times 10^{4}$ & $3.116 \times 10^{4}$ & $2.724 \times 10^{4}$ \\
\hline$r_{c} \mathrm{~cm}$ & & 50.22 & 47.37 & 48.11 \\
\hline$r_{13} \mathrm{~cm}$ & & 36.56 & 34.49 & 35.02 \\
\hline$T_{\mathrm{o}}$ keV & & 25.42 & 30.30 & 34.39 \\
\hline$T_{-}, \mathrm{keV}$ & & 21.90 & 24.61 & 26.88 \\
\hline$P_{\text {ECRH, }} M W$ & & 50.58 & 39.54 & 38.46 \\
\hline 2 & & 48.94 & 61.78 & 62.17 \\
\hline$\Gamma, \mathrm{MW} / \mathrm{cm}^{2}$ & & 4.103 & 3.070 & 2.605 \\
\hline
\end{tabular}

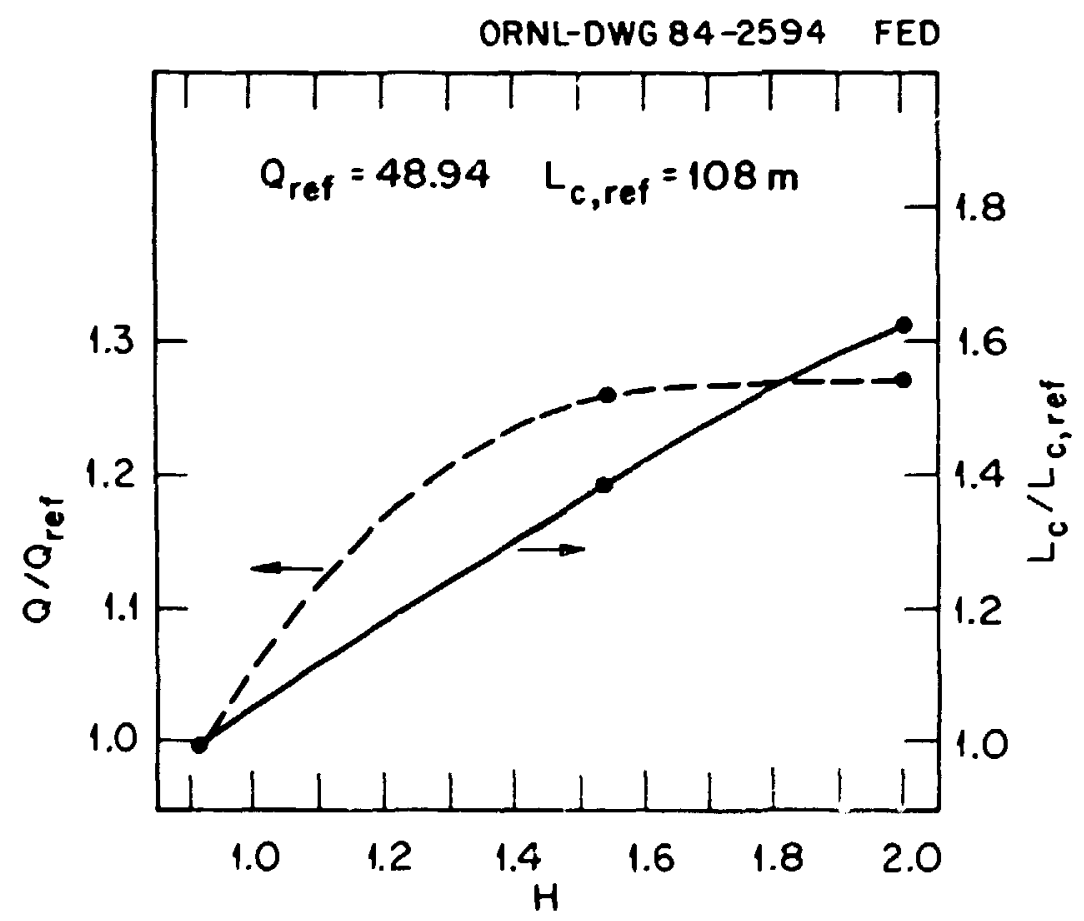

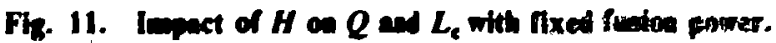




\begin{tabular}{|c|c|c|c|c|}
\hline & $\begin{array}{l}B_{C}=0.75 \\
B_{C}=2.97 \mathrm{~T} \\
F_{c}=0.03\end{array}$ & $\begin{array}{l}g=2.75 \\
G=4.75 \\
H=0.67\end{array}$ & $\begin{array}{l}\text { lysix: } \\
L_{\tau}=130.8 \mathrm{~m} \\
L_{L}=220 \mathrm{~m} \\
P_{\text {Xah }}=0\end{array}$ & \\
\hline & & $B_{\text {max }}=24 I$ & $B_{\max }=20 \mathrm{~T}$ & $B_{1}=18 \mathrm{~T}$ \\
\hline$P_{\text {himan }} \mathrm{MW}$ & & 2615 & 1877 & 1433 \\
\hline$n_{6} \mathrm{~cm}^{-3}$ & & $3.31 \times 10^{4}$ & $3.08 \times 10^{4}$ & $2.02 \times 10^{4}$ \\
\hline$r_{c} \mathrm{~cm}$ & & 49.02 & 53.70 & 56.15 \\
\hline$r_{\mathrm{r}} \mathrm{cm}$ & & 37.29 & 27.15 & 37.02 \\
\hline$T_{c}$ keV & & 28.14 & 30.83 & 33.33 \\
\hline$T_{\infty}$, keV & & 23.75 & 25.17 & 26.62 \\
\hline$B_{c}$ & & 0.425 & 0.480 & 0.502 \\
\hline$P_{\text {ECRH }}$, MW & & 83.94 & 78.57 & 74.99 \\
\hline $\boldsymbol{Q}$ & & 29.16 & 22.28 & 17.71 \\
\hline$\Gamma, \mathrm{MW} / \mathrm{cm}^{2}$ & & 3.84 & 2.47 & 1.78 \\
\hline
\end{tabular}
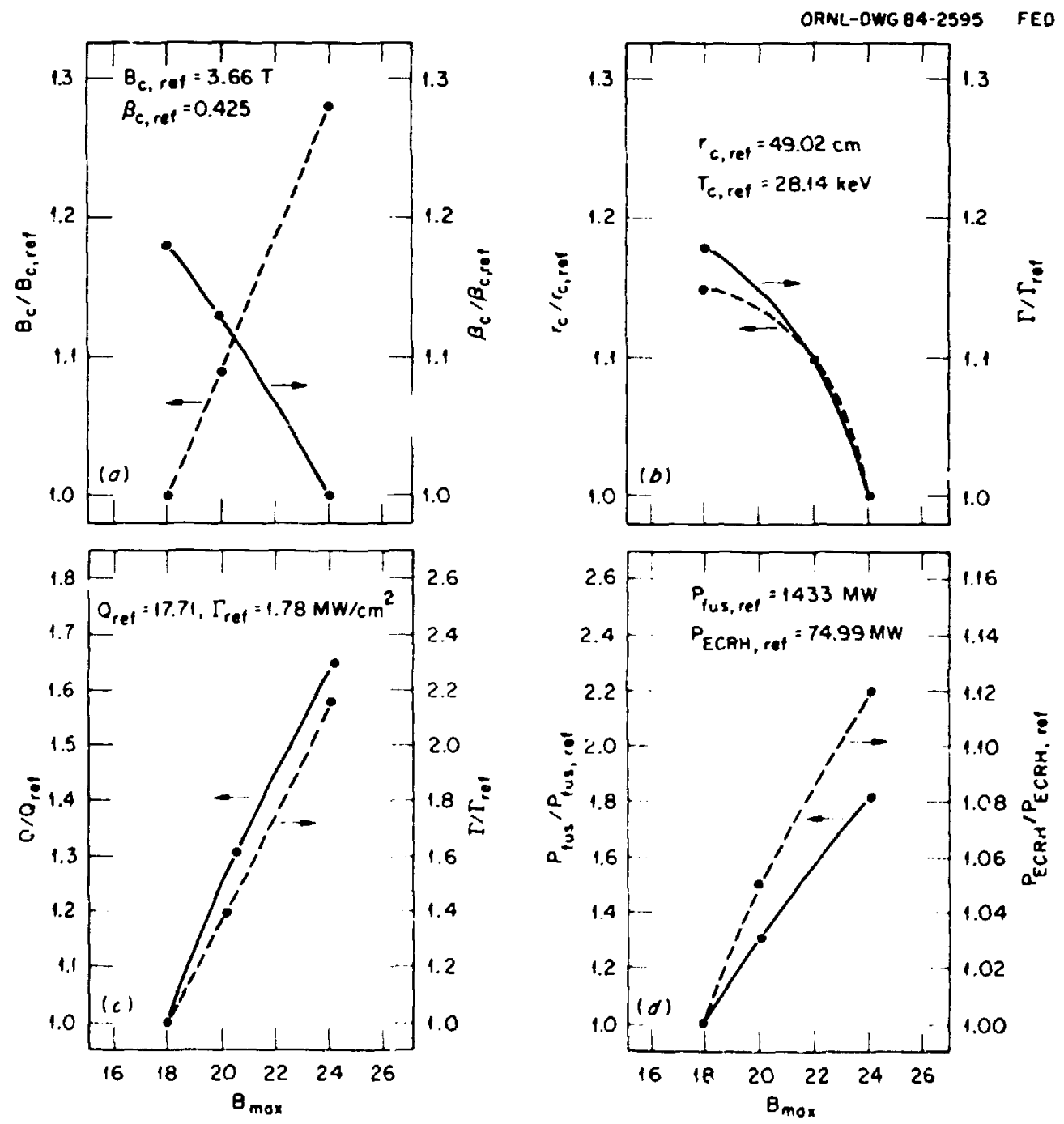

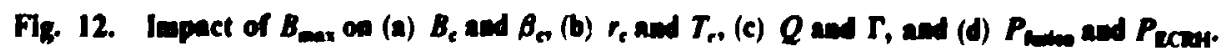




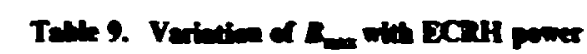

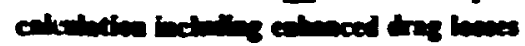

Constants for this analysis:

\begin{tabular}{|c|c|c|c|c|}
\hline & $\begin{array}{l}A_{1}=0.75 \\
B_{0}=2.97 \mathrm{~T} \\
F_{c}=0.03\end{array}$ & $\begin{array}{l}g=275 \\
G=4.75\end{array}$ & $\begin{array}{l}L_{C}=130.8 \mathrm{~m} \\
L_{L}=22 \mathrm{~m} \\
P_{\mathrm{SCAH}}=0\end{array}$ & \\
\hline & & $B_{1-2}=24 \mathrm{~T}$ & $B-=20 \mathrm{~T}$ & $B_{m}=18 \mathrm{~T}$ \\
\hline$\overline{P_{\mathrm{h}} M W}$ & & 2615 & 1800 & 1300 \\
\hline$n_{5} \mathrm{~cm}^{-3}$ & & $3.550 \times 10^{\circ}$ & $2557 \times 10^{4}$ & $1.973 \times 10^{4}$ \\
\hline$r_{0} \mathrm{~cm}$ & & 46.98 & 51.67 & 54.47 \\
\hline$r_{0} \mathrm{cmn}$ & & 47.39 & 47.42 & 47.66 \\
\hline$T_{\sigma} \mathrm{keV}$ & & $2 \epsilon .62$ & 29.69 & 33.76 \\
\hline$T_{\infty}$ keV & & 2284 & 24.76 & 27.06 \\
\hline$\beta_{\varepsilon}$ & & 0.425 & 0.477 & 0.497 \\
\hline$P_{\text {ECH, }}, M W$ & & 135.8 & 123.8 & 117.1 \\
\hline$Q$ & & 18.57 & 13.99 & 10.60 \\
\hline I. $\mathrm{MW} / \mathrm{cm}^{2}$ & & 3.964 & 2434 & 1.652 \\
\hline
\end{tabular}
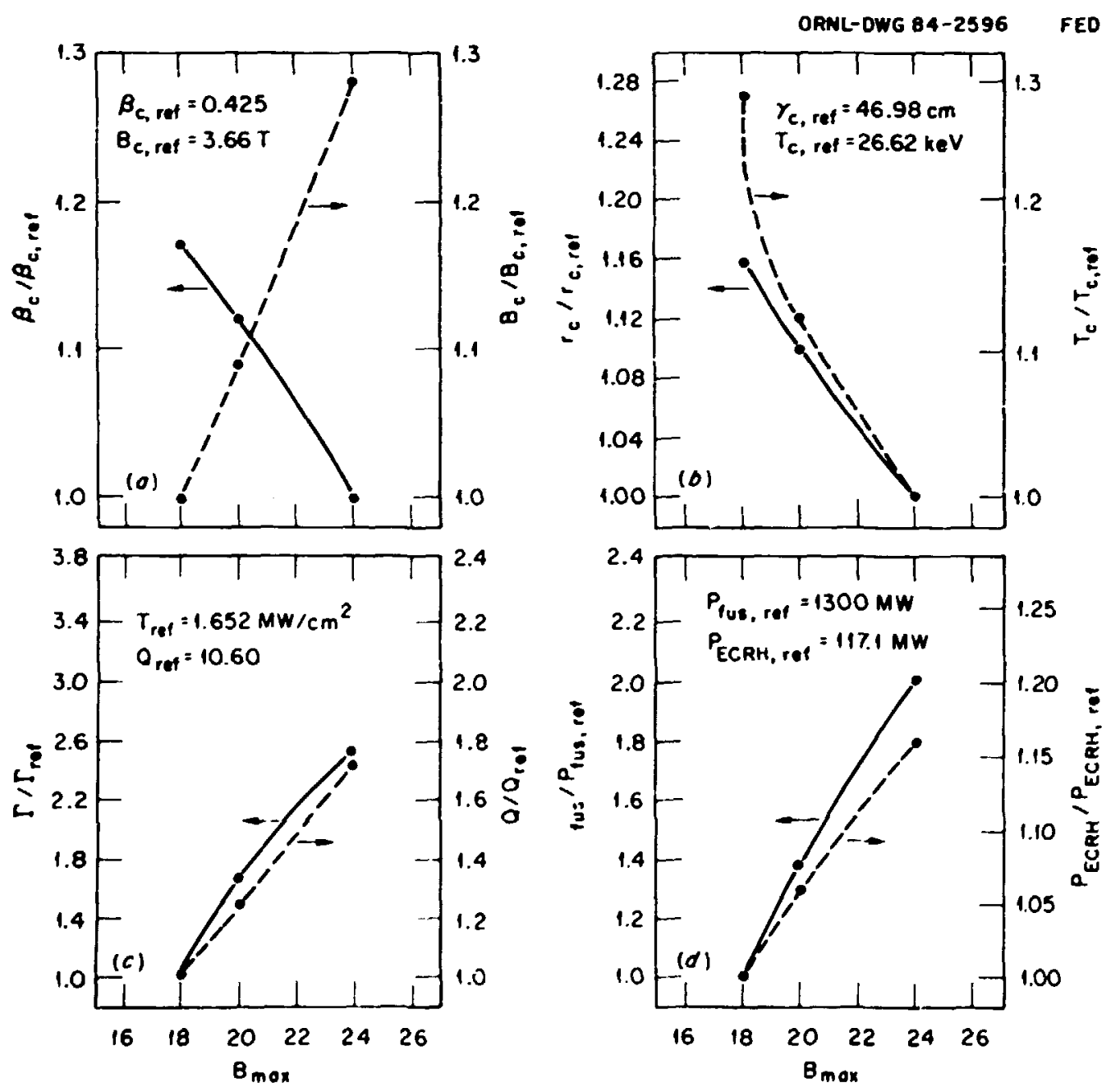

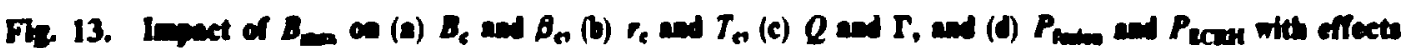
of entaveed ding laves incladed. 


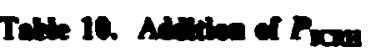

Conatants for this analysis:

\begin{tabular}{|c|c|c|c|c|}
\hline & $\begin{array}{l}A_{C}=0.75 \\
A_{c}=0.334 \\
B_{C}=2.97 \mathrm{~T} \\
B_{c}=5.3 \mathrm{~T}\end{array}$ & $\begin{array}{l}B_{m}=24 \mathrm{~T} \\
f_{E=0.03}=0.75 \\
g=2.75\end{array}$ & $\begin{array}{l}G=4.75 \\
H=0.67 \\
L_{2}=130.8 \mathrm{~m} \\
L_{4}=22 \mathrm{~m}\end{array}$ & \\
\hline & & $P_{\mathrm{YCAH}}=30 \mathrm{MW}$ & $P_{\text {IOAH }}=15 \mathrm{MW}$ & $P_{\mathrm{XOH}}=0$ \\
\hline$-M W$ & & 2462 & 2125 & 1831 \\
\hline $\mathrm{cm}^{-3}$ & & $3.38 \times 10^{4}$ & $3.16 \times 10^{4}$ & $2.87 \times 10^{4}$ \\
\hline $\mathrm{cm}$ & & 46.2 & 45.0 & 44.9 \\
\hline $\mathrm{cm}$ & & 38.1 & 37.1 & 37.0 \\
\hline Co keV & & 28.9 & 30.8 & 32.5 \\
\hline co keV & & 229 & 24.1 & 26.2 \\
\hline$P_{\text {ECaH }}, \mathbf{M W}$ & & 90.8 & 81.8 & 76.8 \\
\hline & & 19.4 & 20.6 & 21.9 \\
\hline $\mathrm{r}, \mathrm{MW} / \mathrm{cm}^{2}$ & & 3.90 & 3.43 & 296 \\
\hline
\end{tabular}
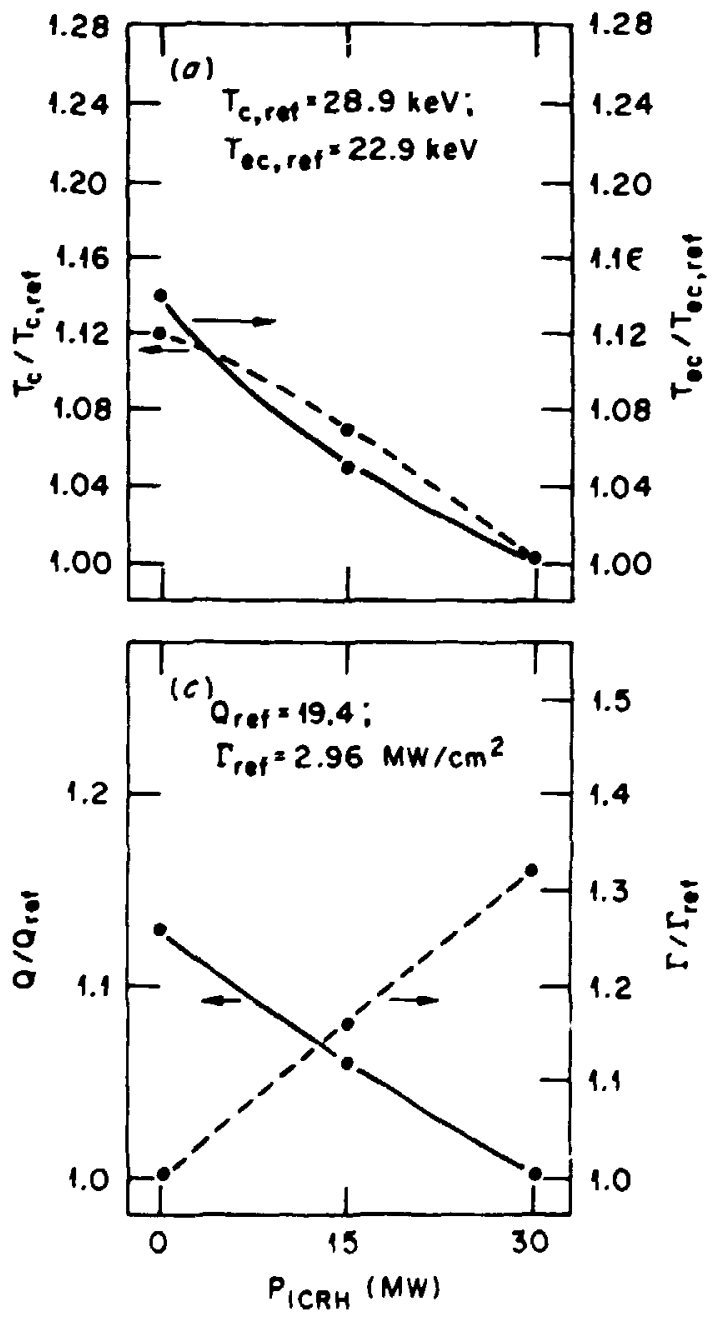

ORNL-DWG 84-2597 FEO

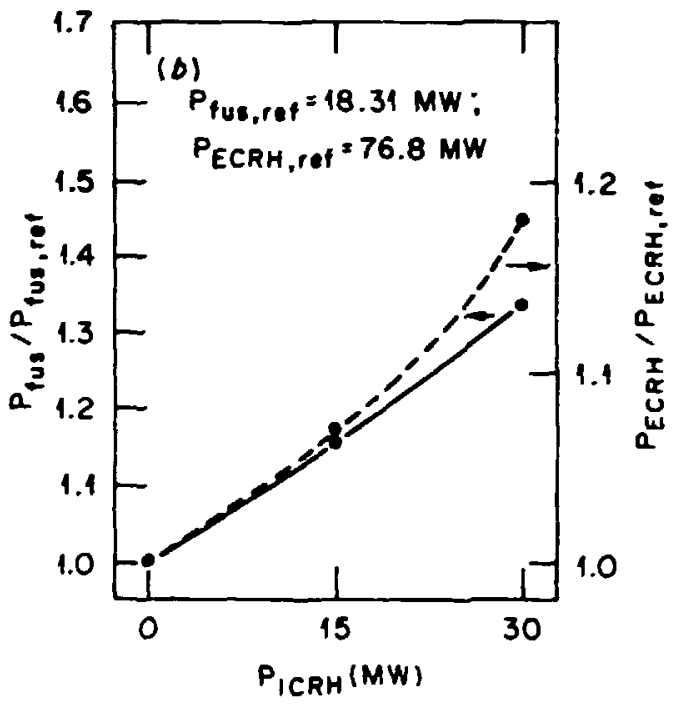

Pre. 14. Inpact of $P_{\text {xar }}$ on (a) $T_{c}$ and $T_{\text {an }}$ (b) $P_{\text {num and }} P_{\text {rand }}$ and (c) $Q$ and $\Gamma$. 
taken into account in the electron power balance, 9 the figures of merit $Q$ and $\Gamma$ drop as much as 36\% (from $Q=21.9$ in Table 10 to $Q=13.98$ in Table 11) and 7\%, respectively. Despite these differences in absolute values, the results shown in Table 11 and Fig. 15 indicate that the higher the valus of $P_{I C R H}$ input to the central cell at ignition conditions, the poorer the $Q$ value will be.

\subsection{Variation of $B_{\mathrm{e}}$ and $\beta_{\mathrm{e}}$}

Changes in plasma performance due to the simultaneous variation of $P_{\text {fuaiva, }} B_{\mathrm{c}}$ and $\beta_{c}$ with $B_{c}^{2} \beta_{c}$ unchanged, were investigated. With $H, L_{c}$ and $B_{\max }$ held fixed, both the central-cell ion and electron temperatures and the end-cell ECRH power requirements increase with higher values of the central-cell field $B_{c}$. The increase in $B_{c}$ also contributes to a reduction in the central-cell radius $r_{c}$ and $P_{\text {fucion. }}$ As a consequence, the two figures of merit are reduced, $Q$ by $40 \%$ and $\Gamma$ by $27 \%$, as $B_{c}$ increases from 3.0 to $3.24 \mathrm{~T}$. The details of this study are indicated in Table 12 and Fig. 16. The ECRH model of ref. 9 was applied to examine the effect on plasma performance of the variation of $B$ and $\beta_{c}$ combined with increased electron drag loss. Results of this study can be found in Table 13 and Fig. 17. In Fig. $17(\mathrm{c})$, the value of $P_{\mathrm{ECRH}}$ actually decreases with increasing $B_{\mathrm{c}}$, as opposed to the slight increases with higher values of $B_{\mathrm{c}}$ shown by Fig. 16(c). Despite the decrease in $P_{E C R H}$, the $Q$ value still decreases with increasing $B_{c}$, because the reduction in $F_{\text {fusion }}$ overwhelms the benefit brought about by decreasing the value of $P_{E C R H}$ [see Fig. 17(ن)]. Comparing the rate of change in $Q$ with that of $B_{c}$ between Tables 12 and 13, one quickly realizes that the increased electron drag losses 9 reduce the impact of $B_{\mathrm{c}}$ variations on $Q$ from a $2.34 \%$ change in $Q$ per unit change in $B_{c}$ to a $1.71 \%$ change. 


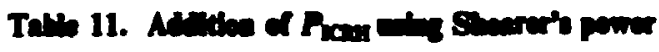

colvelation Entind

Comitents for this analyai:

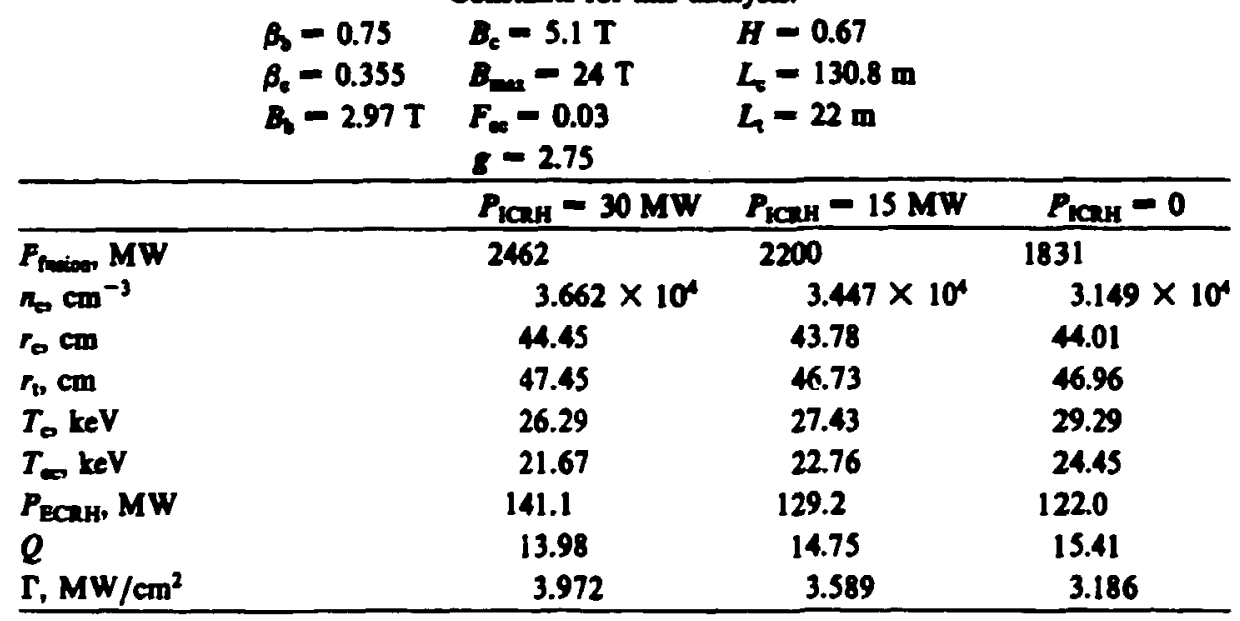
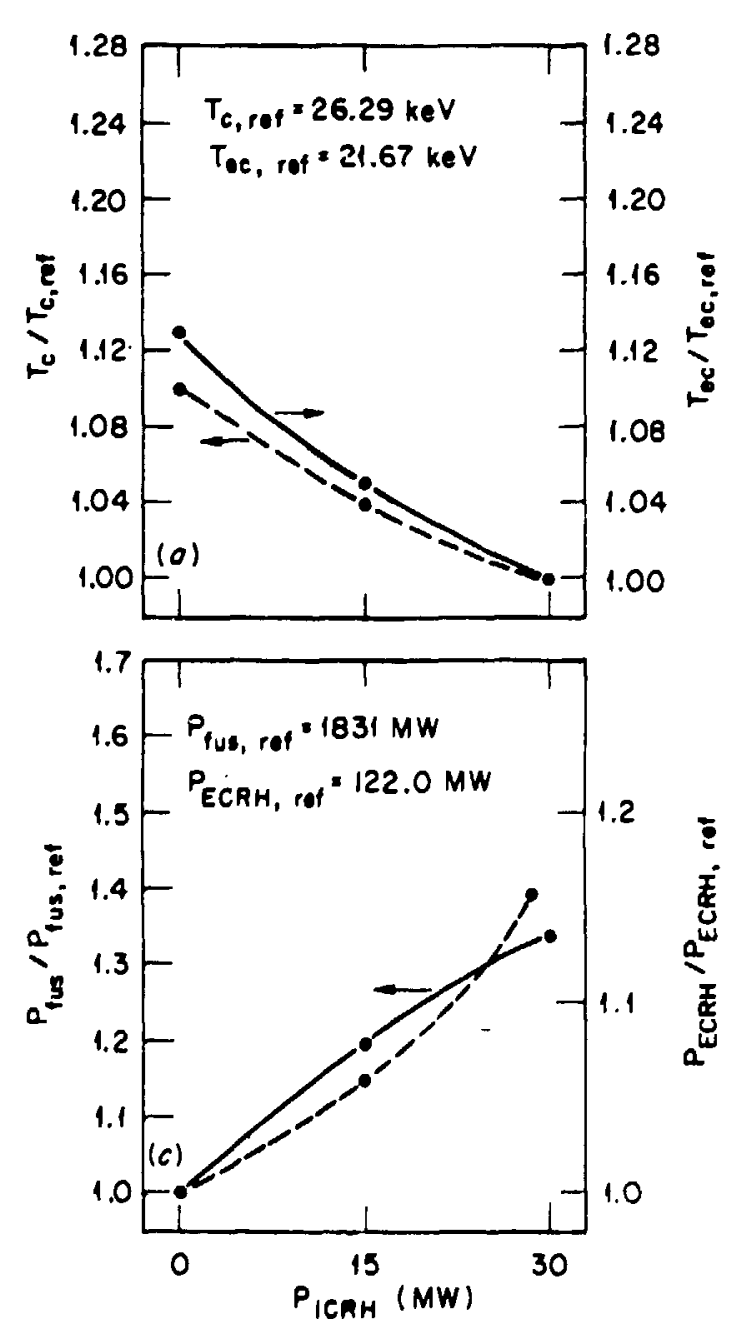

ORNL-DWG 84-2398 FED

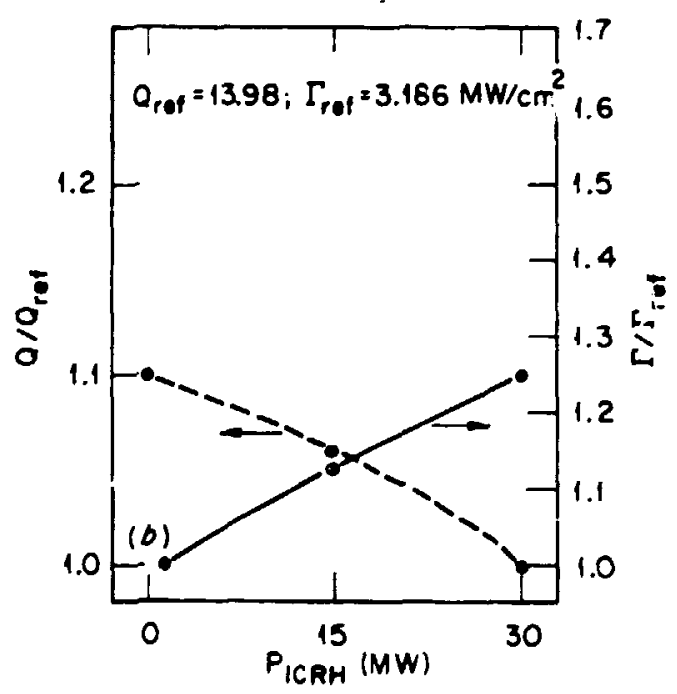

Fl. 15. Inpact of $P_{\text {ran }}$ on (a) $T_{c}$ and $T_{\text {es }}$ (b) $Q$ and $\Gamma_{\text {, and }}(c) P_{\text {mom and }} P_{\text {ras }}$ the eficets of entranced dras loseses beladed. 
Tolle 12 Vartation of $A_{8}$ and $P_{8}$

\begin{tabular}{|c|c|c|c|c|}
\hline & $\begin{array}{l}B_{1}=0.75 \\
B_{1}=2.97 \mathrm{~T} \\
B_{\max }=24 \mathrm{~T}\end{array}$ & $\begin{array}{l}\text { Conetants for this } \\
F_{\alpha=0.03}=0.75 \\
g=2.75 \\
G=4.75 \\
H=0.65\end{array}$ & $\begin{array}{l}\text { nalyaix: } \\
L_{\varepsilon}=150 \mathrm{~m} \\
L_{1}=21.12 \mathrm{~m} \\
P_{\text {ICaH }}=0\end{array}$ & \\
\hline & & $\begin{array}{l}B_{c}=3 \mathrm{~T}, \\
B_{\varepsilon}=0.70\end{array}$ & $\begin{array}{c}B_{c}=3.11 \mathrm{~T}, \\
\beta_{c}=0.65\end{array}$ & $\begin{array}{c}B_{\varepsilon}=3.24 \mathrm{~T}, \\
B_{c}=0.60 \\
\end{array}$ \\
\hline$P_{\text {hime }} \mathrm{MW}$ & & 2615 & 2256 & 1923 \\
\hline$n_{0} \mathrm{~cm}^{-3}$ & & $2.188 \times 10^{4}$ & $2.054 \times 10^{4}$ & $1.924 \times 10^{4}$ \\
\hline$r_{0} \mathrm{~cm}$ & & 67.94 & 65.70 & 63.48 \\
\hline$r_{0} \mathrm{~cm}$ & & 38.25 & 38.25 & 38.25 \\
\hline$T_{0} \mathrm{keV}$ & & 29.72 & 31.35 & 33.69 \\
\hline$T_{\infty}$ keV & & 23.39 & 24.45 & 25.50 \\
\hline$P_{\text {ECaH }}, M W$ & & 77.74 & 78.37 & 79.45 \\
\hline $\boldsymbol{Q}$ & & 32.44 & 27.68 & 23.18 \\
\hline$\Gamma_{1} \mathrm{MW} / \mathrm{cm}^{2}$ & & 2.34 & 2.09 & 1.85 \\
\hline
\end{tabular}
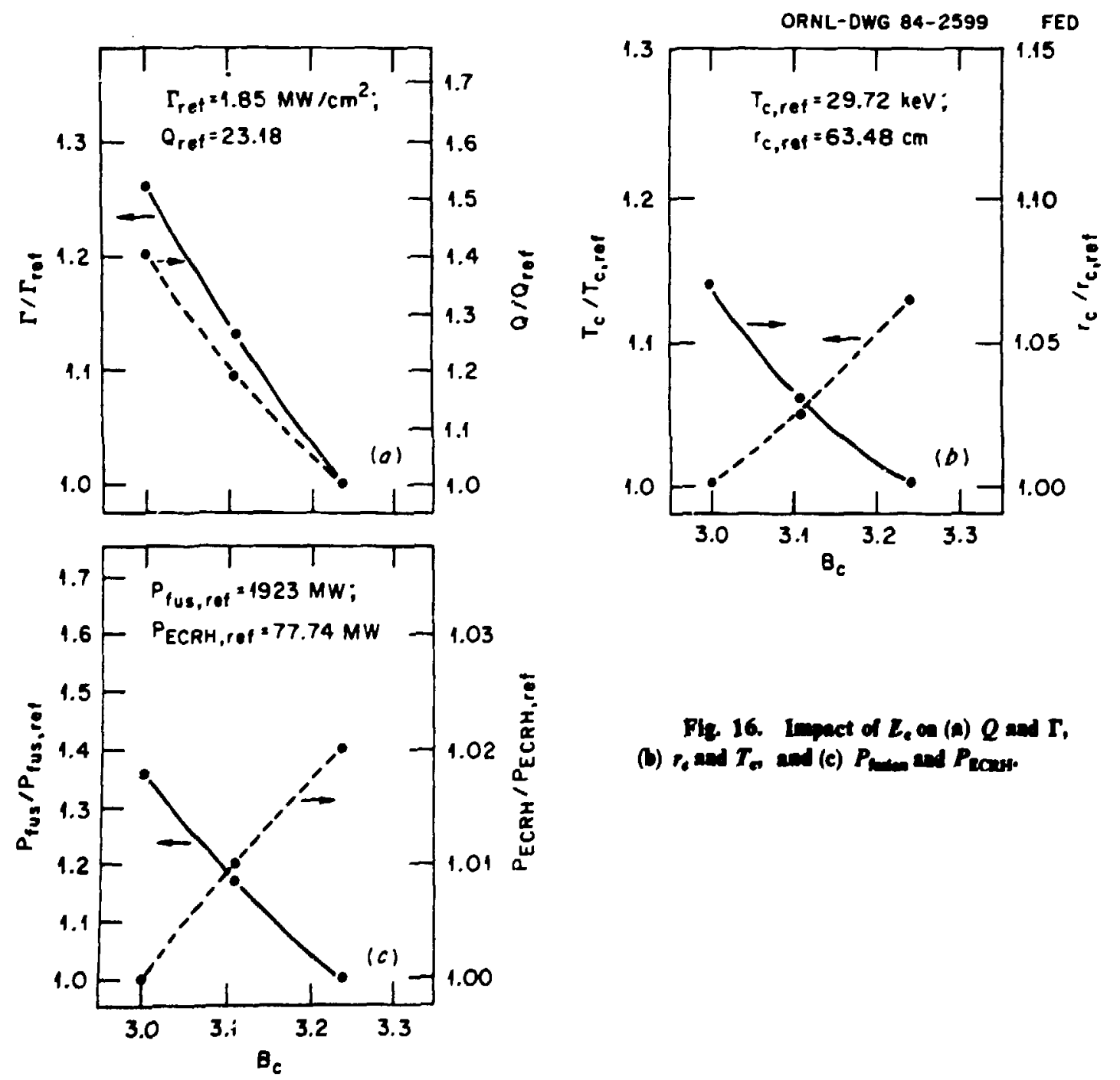

Pig. 16. Impact of $L_{a}$ on (a) $Q \mathrm{and} r$, (b) $r_{c}$ and $T_{n}$ and (c) $P_{\text {mand and }} P_{\text {LCOH }}$ 
Talle 13. Vartintion of $B_{\varepsilon}$ en $B_{\varepsilon}$ with ECRH power

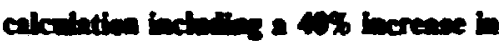
electinen bles bones

Coostants for this andyris:

\begin{tabular}{|c|c|c|c|c|}
\hline & $\begin{array}{l}B_{b}=0.75 \\
B_{b}=2.97 \mathrm{~T} \\
B_{\max }=24 \mathrm{~T}\end{array}$ & $\begin{array}{l}F_{\alpha}=0.03 \\
g=2.75 \\
G=4.75 \\
H=0.67 \\
\end{array}$ & $\begin{array}{l}L_{\tau}=130.8 \mathrm{~m} \\
L_{4}=22 \mathrm{~m} \\
P_{\mathrm{YCAH}}=0\end{array}$ & \\
\hline & & $\begin{array}{l}B_{c}=3 \mathrm{~T}, \\
B_{c}=0.70\end{array}$ & $\begin{array}{c}B_{c}=3.11 \mathrm{~T}, \\
\beta_{c}=0.65\end{array}$ & $\begin{array}{c}B_{c}=3.24 \mathrm{~T} \\
B_{c}=0.60 \\
\end{array}$ \\
\hline$P_{\text {finion }}, \mathrm{MW}$ & & 2880 & 2615 & 2400 \\
\hline $\mathrm{R}_{\mathrm{s}} \mathrm{cm}^{-3}$ & & $3.666 \times 10^{4}$ & $3.550 \times 10^{4}$ & $3.412 \times 10^{4}$ \\
\hline$r_{c} \mathrm{~cm}$ & & 48.44 & 46.98 & 46.07 \\
\hline$r_{t}, \mathrm{~cm}$ & & 47.75 & 47.35 & 47.48 \\
\hline$T_{c}, k e V$ & & 25.82 & 26.62 & 27.60 \\
\hline$T_{\infty}, \mathrm{keV}$ & & 22.37 & 22.84 & 23.46 \\
\hline$P_{\text {ECRH }}, \mathbf{M W}$ & & 141.8 & 135.8 & 132.1 \\
\hline $\boldsymbol{Q}$ & & 19.62 & 18.57 & 17.49 \\
\hline$\Gamma, \mathrm{MW} / \mathrm{cm}^{2}$ & & 4.23 & 3.96 & 3.72 \\
\hline
\end{tabular}
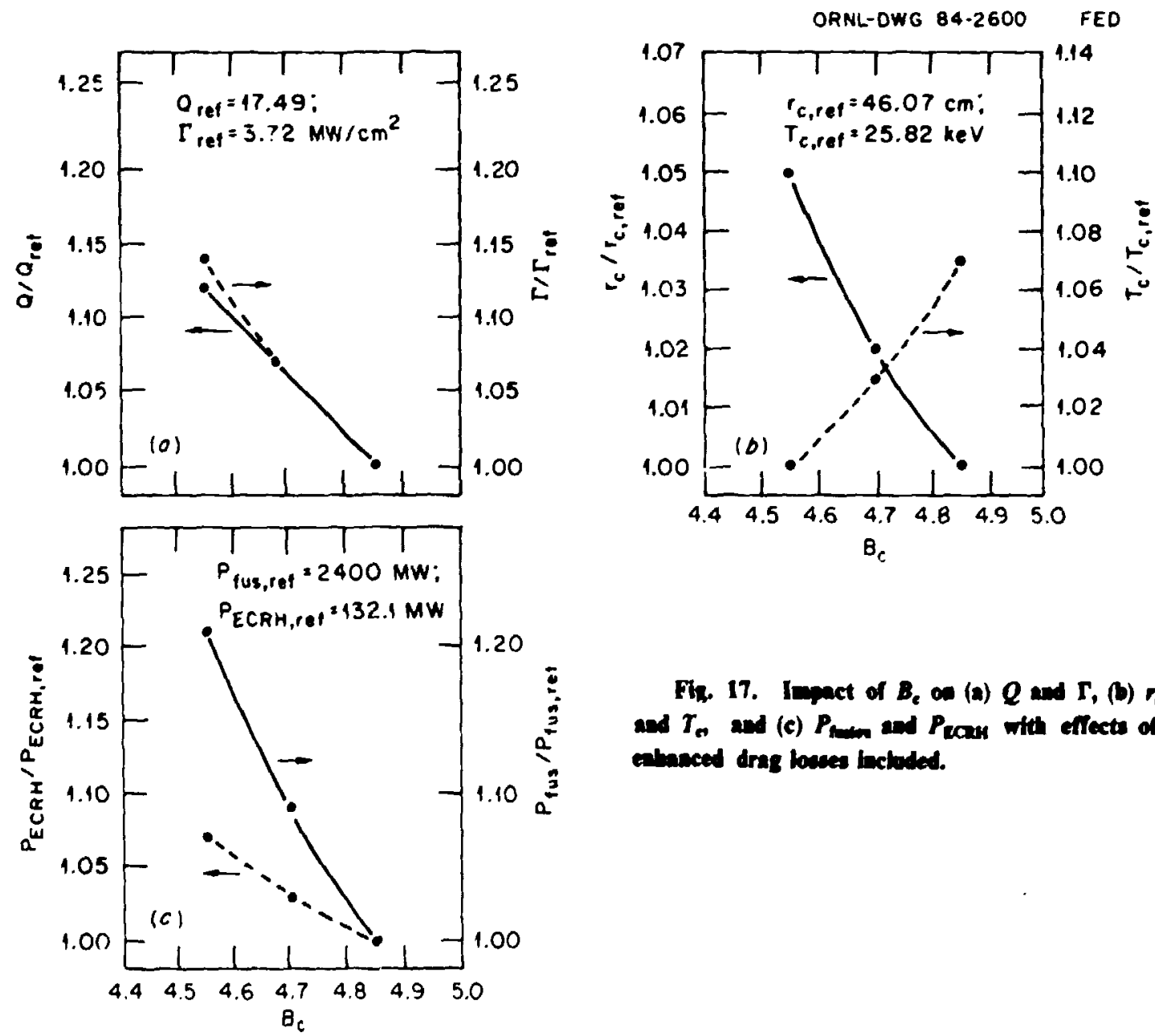

Fix. 17. Inenct of $B_{c}$ an (a) $Q$ and $\Gamma_{1}(b) r_{c}$ and $T_{e}$ and (c) $P_{\text {fum and }} P_{\text {rous }}$ ifth eficets of

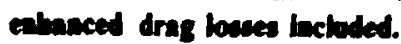




\section{CONCLUSIONS}

From the results of the prametric analyses, the following conclusions can be drawn.

- With fixed $L_{c}$ and $H$, it is advantageous to design for a higher value of $P_{\text {fusion }}$ that allows a higher value of $\boldsymbol{\beta}_{\mathrm{c}}$ at lower fields. Alternatively, for a fixed $\boldsymbol{P}_{\text {fusion }}$ it is possible to operate with a shorter central-cell length.

- It is beneficial to operate at the highest choke coil field permitted by technology, because the higher this magnetic field is, the more fusion power can be produced. (There is, of course, the issue of recirculating power to the normal insert coil.)

- With $L_{c}, \beta_{c}, B_{c}$ and $B_{\max }$ constant, addiag ICRH power to the central cell results in a substantial increase in $\boldsymbol{P}_{\text {fusion }}$ and $\boldsymbol{\Gamma}$ but a moderate decrease in $\boldsymbol{Q}$. Alternatively, for a fixed $P_{\text {fusion, }}$ a substantial decrease in $L_{c}$ is realized.

- With $B_{c}, \beta_{c}, P_{\text {fusion, }}$ and $\boldsymbol{B}_{\max }$ constant, an improved plasma performance can be achieved at a lower value of $B_{\mathrm{b}}$. This : true because with fixed $\beta_{\mathrm{b}}$, ECRH power requirements decrease with decreasing $B_{\mathrm{b}}$. However, if $\beta_{\mathrm{b}}$ is varied under the constraints of constant-beta-corrected $B_{\mathrm{b}}$, a higher value of $B_{\mathrm{b}}$ is desirable because the central-cell ion density decreases, as opposed to being constant.

- The increased electron drag loss in computing the ECRH power requirements amplifies the advantage of using a higher value of $B_{\mathrm{a} \text { ax }}$ but reduces the plasma performance for the case of adding ICRH power to the central cell at ignition.

- With $H, L_{c}$, and $B_{\max }$ constant, a decrease in $g$ results in increased $Q$ mainly because of lower ECRH power requirements. However, an optimum value for $\Gamma$ seems to exist at $g=2.75$.

- A low ${ }^{\circ} \propto$ value would yield a better plasma performance because less ECRH power is required to provide collisional filling of cold electrons into the thermal barrier.

- For fixed $B_{\mathrm{c}}$ and $\beta_{\mathrm{c}}$, it is best to operate at the lowest $H$ value possible. A higher $H$ value would require a longer $L_{c}$ for a given $Q$ value. 


\section{ACKNOWLEDGMENTS}

The authors wish to express their appreciation to Dr. B. G. Logan of LLr. a his valuable advice and suggestions during the course of this study.

We also express out thanks tu Drs. D. T. Blackfield and S. K. Borowski for reviewing the draft and providing excellent suggestions anci comments. 


\section{REFTRENCES}

1. R. W. Moir, W. L. Barr, and D. J. Bender, Mirror Reactor Studies, UCRL78122, Lawrence Livermore Natl. Lab., Livermore, Calif., 1977.

2. G. I. Dimov, V. V. Zakaidov, ard M. E. Kishinevskii, "Thermonuclear Confineinenı System with Twin Mirror Systems," Fiz. Plazmy 2, 597 (1976) [Sov. J. Plasma Phys. 2, 326 (1976)].

3. T. K. Fowler and B. G. Logan, "Tandem Mirror Reactor," Comments Plasma Phys. Controlled Fusion 2, 167-72 (1977).

4. R. W. Moir, W. L. Barr, and G. A. Carlson, Preliminary Design Study of the Tandem Mirror Reactor (TMR), UCRL-52302, Lawrence Livermore Natl. Lab., Livermore, Calif., 1978.

5. D. E. Baldwin and B. G. Logan, "An Improved Mirror Fusion Reactor," Phys. Rev. Lett. 43, 1318 (1979).

6. G. A. Carlson et al., Tandem Mirror Reactor with Thermal Barriers, UCRL52836, Lawrence Livermore Natl. Lab., Livermore, Calif., 1979.

7. B. G. Logan, C. D. Henning, and G. A. Carlson, Mirror Advanced Reactor Study Interim Report, UCRL-53333, Lawrence Livermore Natl. Lab., Livermore, Calif., 1983.

8. R. B. Campbell, TMRBAR-A Sode to Calculate Plasma Parameters for Tandem Mirror Reactors Operating in the MARS Mode, UCID-19875, Lawrence Livermore Natl. Lab., Livermore, Calif., 1982.

9. J. W. Shearer, Hot Electrons in the Anchor Region of the Axicell Design of the MFTF, UCID-19577, Lawrence Livermore Natl. Lab., Livermore, Calif, 1982.

10. D. E. Baldwin et al., Physics Basis for MFTF-B, UCID-18496, Lawrence Livermore Natl. Lab., Livermore, Calif., 1980.

11. R. S. Devoto, "Heating and Pumping Studies in the End Cells of Tandem Mirror Reactors," presented at the 1983 IEEE International Conference on Plasma Science, San Diego, May 23-25, 1983, to be published in the proceedings. 


\section{Appendix A}

\section{CONSTRAINTS}

The following constraints were applied during the parametric analyses.

1. Approximate global energy balance for ignition conditions at $\boldsymbol{P}_{\text {ICRH }}=\mathbf{0}$ with constant $\phi_{e}, g, L_{c}, T_{c}, T_{e c}, L_{c}$, and $L_{i}$ :

$\left(B_{\sqrt{ }} / B_{\max }\right)^{2} B_{c} \sqrt{1-\beta_{c}}\left[1+0.044\left(B_{\operatorname{mad}} / B_{\mathrm{t}}\right)\right]^{3.33}=$ const

2. Trapped particle stability foi fixed end-cell fields and dimensions:

$3.6 \times 10^{3}\left(g_{\mathrm{b}} n_{\mathrm{pesd}} / n_{\mathrm{c}}\right)\left(B_{d} / r_{\mathrm{c}}^{2}\right) \sqrt{1-\beta_{\mathrm{c}}} \geqslant 0.5$

3. Conservation of magnetic flux:

$r_{c}^{2} B_{c} \sqrt{1-\beta_{c}}=$ const .

4. MHD stability:

$$
\begin{aligned}
& B_{\mathrm{c}}^{2} \beta_{\mathrm{c}}=\text { const , } \\
& B_{b} \sqrt{1-\beta_{b}}=\text { const , } \\
& B_{\sqrt{ }} B_{\mathrm{c}}=\text { const }, \\
& \beta_{1} \leqslant 0.066 \text {, } \\
& \beta_{\mathrm{c}} \leqslant 0.90 \text {. }
\end{aligned}
$$




\section{Appeadix B}

\section{DEFINITIONS OF PARAMETERS}

$B_{\mathrm{b}} \quad$ Vacuum magnetic field of the plug bottom, $\mathrm{T}$

$B_{\mathrm{c}} \quad$ Vacuum magnetic field of the central cell, $T$

$B_{\max } \quad$ Peak magnetic field of the choke coil, $T$

B. $\quad$ Vacuum magnetic field of the transition region, $T$

$C_{\alpha} \quad$ Thermal alpha particle density fraction of the central cell

$F_{\text {oc }} \quad$ Density fraction of central-cell electrons at the plug bottom

$g$ Ratio of passing and trapped ion density to passing ion density at the plug bottom

$G \quad$ Ratio of passing, trapped, and sloshing ion density to passing ion density

$H \quad$ Ratio of the trapped ion current from Fokker-Planck calculations to the trapped ion current from the Futch-LoDestro square-well calculations

$L_{\mathrm{c}} \quad$ Length of the central cell, $m$

$L_{q} \quad$ Length of the transition region, $m$

$n_{c} \quad$ Ion density of the central cell, $\mathrm{cm}^{-3}$

$n_{\text {pass }} \quad$ Passing ion density of the plug region, $\mathrm{cm}^{-3}$

$P_{\text {fusion }} \quad$ Fusion power generated, MW

$P_{\text {ECRH }} \quad$ ECRH power input, $M W$

$P_{\text {ICRH }}$ ICRH power input, MW

$Q \quad$ Ratio of fusion power generated to total power input

$r_{c} \quad$ Racius of the central cell, $\mathrm{cm}$

$T_{\mathrm{c}} \quad$ Ion temperature of the central cell, $\mathrm{keV}$

$T_{c c} \quad$ Electron temperature of the central cell, keV

$\overline{\beta_{b}} \quad$ Volume-averaged beta of the plug

$\overline{\beta_{c}} \quad$ Volume-averaged beta of the central cell

$\overline{\beta_{t}} \quad$ Volume-averaged beta of the transition region

$\phi_{e} \quad$ Electron confinement potential of the central cell, keV

$\Gamma \quad$ Neutron wall loading, $\mathrm{MW} / \mathrm{cm}^{2}$ 
ORNL/FEDC-83/11

Dist. Category UC-20 c,d

\section{INTERNAL DISTRIBUTION}

1. L. A. Berry

2. R. D. Donaldson

3. R. A. Dory

4. J. L. Dunlap

5. J. C. Glowienka

6. H. H. Haselton

7. T. W. Pickel

8. M. J. Saltmarsh

9. R. W. Schaich

10. T. E. Shannon

11. J. Sheffield

12. M. Siman-Tov

13. V. C. Srivastava
14. N. A. Uckan

15. S. K. Borowski

16. F. W. Wiffen

17-21. K. F. Wu

22-26. Y-K. M. Peng

27-28. Laboratory Records Department

29. Laboratory Records, ORNL-RC

30. Central Research Library

31. Document Referense Section

32. Fusion Energy Division Library

33. Fusion Energy Division Publications Office

34. ORNL Patent Offía.

\section{EXTERNAL DISTRIBUTION}

35-39. R. B. Campbell, TRW Defense and Space Systems, Inc., I Space Park, Redondo Beach, CA 92078

40. M. A. Abdou, School of Engineering and Applied Science, 6288 Boelter Hall, University of California, Los Angeles, CA 90024

41. C. A. Anderson, Westinghouse Electric Corporation, Advanced Energy Systems Division, P.O. Box 158, Madison, PA 15663

42. J. L. Anderson, CMB-3, Mail Stop 34!,, Los Alamos National Laboratory, P.O. Box 1663, Los Alamos, NM 87545

43. C. C. Baker, FPP/208, Argonne National Laboratury, 9700 South Cass Avenue, Argonne, IL 60439

44. D. S. Beard, Office of Fusion Energy, Office of Energy Research, Mail Stop G-256, U.S. Department of Energy, Washington, DC 20545

45. K. L. Black, Department E452, McDonnell Douglas Astronautics Company, P.O. Box 516, St. Louis, MO 63166

46. R. Botwin, C47-05, Grumman Aerospace Corporation, P.O. Box 31, Bethpage, NY 11714 
47. W. B. Briggs, McDonnell Douglas Astronautics Company, P.O. Box 5i6, St. Lovis, MO 63166

48. J. N. Brooks, FPP/207, Argonne National Laboratory, 9700 South Cass Avenue, Argonne, IL 60439

49. S. C. Burnett, GA Technologies, Inc., P.O. Box 81608, San Diego, CA 92138

50. J. D. Callen, Department of Nuclear Engineering, University of Wisconsin, Madison, WI 53706

51. D. R. Cohn, MIT Plasma Fusion Center, 167 Albany Street, Cambridge, MA 02139

52. J. W. Coursen, C36-05, Grumman Aerospace Corporation, P.O. Box 31, Bethpage, NY 11714

53. R. W. Conn, School of Chemical, Nuclear, and Thermal Engineering, Boelter Hall, University of California, Los Angeles, CA 90024

54. J. G. Crocker, Ej\&G Idaho, P.O. Box 1625, Idaho Falls, ID 83401

55. G. R. Dalton, Department of Nuclear Er : 'neering Science, Nuclear Science Center, University of Florida, Gainesville, FL 32611

56. R. C. Davidson, Massachusetts Institute of Technology, 77 Massachusetts Avenue, Cambridge, MA 02139

57. N. A. Davies, Office of Fusion Energy, Office of Energy Research, Maii Station G-256, U.S. Department of Energy, Washington, DC 20545

58. S. O. Dean, Director, Fusion Energy Development, Science Applications, Inc., 2 Professional Drive, Suite 249, Gaithersburg, MD 20760

59. J. F. Decker, Office of Fusion Energy, Department of Energy, Mail Stop G-256, Washington, DC 20545

60. D. DeFreece, E451, Building 81/i/B7, McDonnell Douglas Astronau'ics Company, P.O. Box 516, St. Louis, MO 63166

61. I. N. Doggett, L-441, Lawrence Livermore Nationa! Laboratory, P.O. Box 808, Livermore, CA 94550

62. H. Dreicer, Division Leader, CRT, Los Alamos National Laboratory, P.O. Box 1663, Los Alamos, NM 87545

63. D. Ehst, Argonne National Labsratory, 9700 South Cass Avenue, Argonne, IL 60439

64. F. Farfaletti-Casali, Engineering Division, Joint Research Center, Ispra Establishment, 21020 Ispra (Varese), Italy

65. P. A. Finn, Fusion Power Program, Argonne National Laboratory, 9700 South Cass Avenue, Argonne, IL 60439

66. H. K. Forsen, Bechtel Group, Inc., Research \& Engineering, P.O. Box 3965, San Francisco, CA 91119

67. J. S. Foster, Jr., Building R4-2004, TRW Defense and Space Systems, 1 Space Park, Redondo Beach, CA 90278 
68. T. K. Fowler, Associate Director for MFE, L-436, Lawrence Livermore National Laboratory, P.O. Bex 808, Livermore, CA 94550

69. J. W. French, EBASCO Services, Inc., Forrestal Campus, CN-59, Princeton University, Princeton, NJ 08544

70. H. P. Furth, Director, Princeton Plesma Physics Laboratory, P.O. Box 451, Princeton, NJ 08544

71. J. G. Gavin, Jr., President, A01-11, Grumman Aerospace Corporation, P.O. Box 31, Bethpage, NY 11714

72. G. Gibson, Westinghouse Electric Corporation, Advanced Energy Systems Division, P.O. Box 158, Madison, PA 15663

73. I. R. Gilleland, Manager, Fusion Project, GA Technologies, Inc., P.O. Box 81608, San Diego, CA 92138

74. M. Y. Gohar, Argonne National Laboratory, 9700 South Cass Avenue, Argonne, IL 60439

75. R. W. Gould, Department of Applied Physics, California Institute of Tecnnology, Pasadena, CA 91109

76. M. W. Griffin, Department E236, McDonnell Douglas Astronautics Company, P.O. Box 516, St. Louis, MO 63166

77. C. R. Head, Office of Fusion Energy, Department of Energy, Mail Stop G-256, Washington, DC 20545

78. C. D. Henning, Lawrence Livermore National Laboratory, P.O. Box 808, Livermore, CA 94550

79. J. J. Holmes, Westinghouse-Hanford Engineering Development Laboratory, P.O. Box 1970, Richland, WA 99352

80. D. Hwang, Princeton Plasma Physics Laboratory, P.O. Box 451, Princeton, NJ 08544

81. J. B. Joyce, Princeton Plasma Physics Laboratory, P.O. Box 451, Princeton, NJ 08544

82. R. A. Krakowsi, CTR-12, Mail Stop 641, Los Alamos National Laboratory, P.O. Box 1663, Los Alamos, NM 87545

83. G. L. Kulcinski, University of Wisconsin, Department of Nuclear Engineering, Engineering Research Building, Room 439, 1500 Johnson Drive, Madison, WI 53706

84. D. L. Kummer, McDonnell Douglas Astronautics Company, P.O. Box 516. St. Louis, MO 63166

85. V'. Marton, Office of Fusion Energy, Office of Energy Research, Mail Station G-256, U.S. Department of Energy, Washington, DC 20545

86. L. G. Masson, EG\&G Idaho, Idaho National Engineering Laboratory, P.O. Box 1625, Idaho Falls, ID 83401

87. D. M. Meade, Princeton Plasma Physics Laboratory, P.O. Box 451, Princeton, NJ 08544 
88. A. T. Miense, Building 107, Post B2, McDonnell Douglas Astronautics Company, P.O. Box 516, St. Louis, MO 63166

89. R. W. Moir, Lawrence Livermore National Laboratory, P.O. Box 808, Livermore, CA 94550

90. D. B. Montgom:ry, MIT Plasma Fusion Center, 167 Albany Street, Cambridge, MA 02139

91. A. E Munier, Grumman Aerospace Company, P.O. Box 31, Bethpage, NY 11714

92. R. E Nygren, FPP/207, Argonne National Laboratory, 9700 South Cass Avenue, Argonne, IL 60439

93. T. Ohkawa, GA Technologies, Inc., P.O. Box 81608, San Diego, CA 92138

94. J. A. O’Toole, Plasma Physics Laboratory, Building I-P, Room 8A, James Forrestal Campus, P.O. Box 451, Princeton, NJ 08544

95. R. R. Parker, Francis Bitter National Magnet Laboratory, 170 Albany Street, Cambridge, MA 02139

96. B. Pease, Culham Laboratory, Abingdon, Oxfordshire OX14 3DB, United Kingdom

97. M. Pelovitz, Princeton Plasma Physics Laboratory, P.O. Box 451, Princeton, NJ 08544

98. F. W. Perkins, Princeton Plasma Physics Laboratory, P.O. Box 451, Princeton, NJ 08544

99. M. Porkulab, Massacinusetts Institute of Technology, 77 Massachusetts Avenue, Cambridge, MA 02139

100. D. E. Post, Princeton Plasma Physies Laboratory, P.O. Box 451, Princeton, NJ 08544 101. L. K. Price, Department of Energy, Oak Ridge Operations, P.O. Box E, Oak Ridge, TN 37831

102. R. E. Price, Office of Fusion Energy, Office of Energy Research, Mail Station G-256, U.S. Department of Energy, Washington, DC 20545

103. F. A. Puhn, GA Technologies, Inc., P.O. Box 81608, San Diego, CA 92138

104. J. Purcell, GA Technologies, Inc., P.O. Box 81608, San Diego, CA 92138

105. R. V. Pyle, University of California, Lawrence Berkeley Laboratory, Berkeley, CA 94720

106. J. M. Rawls, GA Technologies, Inc., P.O. Box 81608, San Diego, CA 92138

107. M. Roberts, Office of Fusion Energy, U.S. Mail Stop G-256, Department of Energy, Washington, DC 20545

108. J. D. Rogers, Los Alamos National Laboratory, P.O. Box 1663, Los Alanos, NM 87545

109. M. L. Rogers, Monsanto Research Corporation, Mound Laboratory Facility, P.O. Box 32, Miamisburg, OH 45342

110. M. N. Rosenbluth, RLM 11.218, Institute for Fusion Studies, University of Texas, Austin, TX 78712 
111. P. H. Rutherford, Princeton Plasma Physics Laboratory, P.O. Box 451, Princeton, NJ 08544

112. J. A. Schmidt, Princeton Plasma Physics Laboratory, P.O. Box 451, Princeton, NJ 08544

113. J. Schultz, MIT Plasma Fusion Center, 167 Albany Street, Cambridge, MA 02139

114. F. R. Scott, Electric Power Research Institute, P.O. Box 10412, Palo Alto, CA 94304

115. G. Sheffield, Princeton Plasma Physics Laboratory, P.O. Box 451, Princeton, NJ 08544

I 16. D. Smith, Materials Science Division, Argonne National Laboratory, 9700 South Cass Avenue, Argonne, IL 60439

117. W. M. Stacey, Jr., Georgia Institute of To:hnology, School of Nuclear Engineering, Atlanta, GA 30332

118. E. Stern, Grumman Aerospace Corporation, CN-59, Forrestal Campus, Princeton, NJ 08544

119. P. M. Stone, Office of Fusion Energy, Office of Energy Research, Mail Station G-256, U.S. Department of Energy, Washington, DC 20545

120. I. N. Sviatoslavsky, Room 33, Engineering Research Building, 1500 Johnson Drive, University of Wisconsin, Madison, WI 53706

121. R. E. Tatro, Manager, Energy Systems, M.Z. 16-1070, General Dynamics-Convair Division, P.O. Box 80847, San Diego, CA 92138

122. F. Thomas, B-20-5, Grumman Aerospace Corporation, Bethpage, NY 11714

123. K. I. Thomassen, Lawrence Livermore National Laboratory, P.O. Box 808, Livermore, CA 94550

124. R. J. Thome, Francis Bitter National Magnet Laboratory, 170 Albany Street, Cambridge, MA 02139

125. C. Trachsel, McDonnell Douglas Astronautics Company, P.O. Box 516, St. Louis, MO 63166

126. A. W. Trivelpiece, Office of Fusion Energy, Office of Energy Research, Mail Station G-256, U.S. Department of Energy, Washington, DC 20545

127. L. R. Turner, Fusion Power Program, Argonne National Laboratory, 9700 South Cass Avenue, Argonne, IL 60439

128. E. H. Valeo, Princeton Plasma Physics Laboratory, P.O. Box 451, Princeton, NJ 08544

129. K. E. Wakefield, Princeton Plasma Physics Laboratory, P.O. Box 451, Princeton, NJ 08544

130. J. C. Wesley, GA Technologies, Inc., P.O. Box 81608, San Diego, CA 92138

131. H. Willenberg, Mathematical Sciences Northwest, Inc., P.O. Box 1887, Bellevue, WA 98009 
132. J. E. C. Williams, Francis Bitter National Magnet Laboratory, 170 Albany Street, Cambridge, MA 02139

133. H. H. Yoshikawa, W/A-62, Hanford Engineering Development Laboratory, P.O. Box 1970, Richland, WA 99352

134. K. M. Young, Princeton Plasma Physics Laboratory, P.O. Box 451, Princeton, NJ 08544

135. N. E. Young, EBASCO Services, Inc., Princeton Plasma Physics Laboratory, P.O. Box 451, Princeton, NJ 08544

136. Bibliothek, Max-Planck-Institut fur Plasmaphysik, D-8046 Garching bei Munchen, Federal Republic of Germany

137. Bibliothek, Institut fur Plasmaphysik, KFA, Postfach 1913, D-5170 Julich, Federal Republic of Germany

138. Library, Centre de Recherches en Physique des Plasmas, 21 Avenue des Bains, 1007 Lausanne, Switzerland

139. Bibliotheque, Service du Confinement des Plasmas, CEA, B.P. No. 6, 92 Fontenay-aux-Roses (Seine), France

140. Documentation S.I.G.N., Department de la Physique du Plasma et de la Fusion Controlee, Association EURATOM-CEA, Centre d'Etudes Nucleaires, B.P. 85, Centre du Tri, 38041 Grenoble, Cedex, France

141. Library, Centre de Recherches en Physique des Plasmas, 21 Avenue des Bains, 1007 Lausanne, Switzerland

142. Library, Culham Laboratory, UKAEA, Abingdon, Oxfordshire, OX14 3DB, England

143. Library, FOM Instituut voor Plasma-Fysica, Rijnhuizen, Jutphaas, Netherlands

144. Library, Institute of Physics, Academia Sinica, Beijing, Pesples Republic of China

145. Library, Institute for Plasma Physics, Nagoya University, Nagoya 464, Japan

146. Library, International Centre for Theoretical Physics, Trieste, Italy

147. Library, JET Joint Undertaking, Abingdon, Oxfordshire, OXI4 3DB, England

148. Library, Laboratorio Gas Ionizzati, Frascati, Italy

149. Plasma Research Laboratory, Australian National Laboratory, P.O. Box 4, Canberra, ACT 2000, Australia

150. Thermonuclear Library, Japan Atomic Energy Research Institute, Tokai, Naka, Ibaraki, Japan

151. Library, Plasma Physics Laboratory, Kyoto University, Gokasho Uji, Kyoto, Japan

152. C. K. Choi, School of Nuclear Engineering, Purdue University, West Lafayette, IN 47907

153. D.W. Sallet, Department of Mechanical Engineering, University of Maryland, College Park, MD 20740 
154. J. D. Kirchner, McDonnell Douglas Astronautics Company, P.O. Box 516, St. Louis, MO 63166

155. Office of the Assistant Manager for Energy Research and Development, Department of Energy, Oak Ridge Operations, Oak Ridge, TN 37830

156-351. Given distribution as shown in TID-4500, Magnetic Fusion Energy (Distribution Category UC-20 c,d: Reactor Materials and Fusion Systems) 